https://doi.org/10.18778/1427-9711.13.02

\author{
Pawet Jokiel \\ Katedra Hydrologii i Gospodarki Wodnej \\ Wydział Nauk Geograficznych, Uniwersytet Łódzki
}

Artykuł wpłynął do redakcji 15.04.2014; po recenzjach zaakceptowany 10.07.2014

\title{
FIZJOGRAFICZNE UWARUNKOWANIA OBIEGU I RETENCJI WODY ORAZ MIGRACJI ZANIECZYSZCZEŃ W MAŁEJ ZLEWNI STREFY PODMIEJSKIEJ LODZI
}

\author{
THE ROLE OF GEOGRAPHICAL CONDITIONS IN \\ WATER CIRCULATION, RETENTION AND MIGRATION \\ OF SUBSTANCES WITHIN A SMALL DRAINAGE BASIN
}

\begin{abstract}
W artykule omówiono kilka zagadnień dotyczących roli warunków fizjograficznych w procesie obiegu wody i migracji innych substancji w obrębie małej zlewni położonej w strefie podmiejskiej dużego miasta (Łodzi). Opisu dokonano w dwu zasadniczych aspektach: formowania odpływu i kształtowania retencji. Wyniki dotyczą w szczególności roli: rzeźby terenu (nachyleń stoków), przepuszczalności gruntu oraz podatności terenu $\mathrm{w}$ procesie formowania różnych form odpływu. W odniesieniu do retencji, omówiono problemy retencji powierzchniowej, w tym koryt i zbiorników wodnych, pojemności wodnej ryzosfery (strefy korzeniowej roślin) oraz zasobów wód podziemnych. Szczególnie dużo uwagi poświęcono zagadnieniom prezentacji i analizy zmienności przestrzennej wymienionych cech zlewni. Do ich zobrazowania wykorzystano mapy rastrowe oparte o siatkę pól elementarnych (rys. 3-11).
\end{abstract}

Słowa kluczowe: obieg wody, małe zlewnie, środkowa Polska

\section{Wprowadzenie}

Od 1997 r., Zespół Badawczy utworzony w Katedrze Hydrologii i Gospodarki Wodnej (KHiGW) Wydziału Nauk Geograficznych Uniwersytetu Łódzkiego prowadził intensywne i wielokierunkowe badania hydrologiczne w okolicach Łodzi. Miały one na celu określenie aktualnego stanu i opracowanie strategii wykorzystania i ochrony zasobów wód powierzchniowych i podziemnych 
w strefie podmiejskiej, a więc na obszarach, gdzie większość elementów biotycznych i abiotycznych środowiska znajduje się pod silną presją i jest intensywnie penetrowana i przekształcana przez różnokierunkową działalność człowieka. Duże aglomeracje miejskie, z uwagi na obcy środowisku typ krajobrazu, stanowią znaczące bariery dla przepływu informacji biologicznej w obrębie sieci ekologicznej. Łódź, w przeciwieństwie do innych wielkich ośrodków miejskich, znajduje się w dość nietypowej sytuacji. Nie leży w dolinie rzecznej, a więc nie „blokuje” żadnego z korytarzy ekologicznych biegnących przez obszary środkowej Polski. Jednocześnie jednak, jej tereny miejskie i podmiejskie są w swoisty sposób „odizolowane” od głównych strumieni informacji biologicznej przemieszczających się między biocentrami. Rodzi to oczywiste problemy ekologiczne i stwarza konieczność ciągłego monitoringu stanu środowiska geograficznego w mieście, a także w jego otoczeniu.

Jako poligon dla tych badań wybrano zlewnię Dzierżąznej o powierzchni ok. $43 \mathrm{~km}^{2}$ należącą do obszaru odwadnianego przez Moszczenicę (rys. 1). Zlewnia jest bowiem zawsze naturalnie i względnie jednoznacznie wyodrębnionym zbiorem ekosystemów, w którym odbywa się lokalny obieg wody, a w dużej mierze również całe lokalne krążenie materii i energii. Można ją więc z powodzeniem traktować, jako elementarną jednostkę przestrzenną o charakterze „zorganizowanej złożoności”. Dzierżązna, a także jej główny dopływ Ciosenka, należały i należą dziś jeszcze do najczystszych strug w obrębie całej strefy podmiejskiej Łodzi. Obie te rzeczki odwadniają obszar bezpośrednio przylegający do terenów miejskich Zgierza i położony niemal w całości w obrębie podłódzkiej strefy ONO (Obszary Najwyższej Ochrony wód podziemnych kredowej niecki łódzkiej). Równocześnie tereny tej zlewni znajdują się w strefie bezpośredniego oddziaływania autostrady A2 i obiektów jej towarzyszących (okolice wsi: Emilia, Rosanów, Ciosny, Dąbrówka i Biała).

$\mathrm{Z}$ uwagi na położenie w otulinie aglomeracji miejskiej Łodzi oraz ze względu na dobrze rozwiniętą sieć komunikacyjną, obszar zlewni Dzierżąznej jest dziś szczególnie intensywnie urbanizowany i zagospodarowywany (np. okolice Dąbrówki Wielkiej, czy Proboszczewic). Jednocześnie, z powodu dużych walorów przyrodniczych, słabych gleb i związanej z tym niskiej produktywności rolnej, znaczny odsetek jej powierzchni jest intensywnie wykorzystywany rekreacyjnie (zespoły działek leśnych okolic: Sokolnik, Rosanowa, Głowy i Ciosen) i turystycznie (obszary wypoczynku sobotnio-niedzielnego - np. Malinka, czy kompleks leśny w północno-wschodniej części zlewni (Szczawin- GłowaLeonów).

Badania w zlewni rozpoczęto od założenia i uruchomienia własnej, specjalnej sieci posterunków obserwacyjnych, wyposażonych w urządzenia pomiarowe: wód powierzchniowych (limnigraf, wodowskaz i posterunek pomiarów hydrochemicznych oraz stałe punkty pomiaru przepływu i własności fizykochemicznych wód rzecznych), wód podziemnych (punkty pomiaru wydajności 


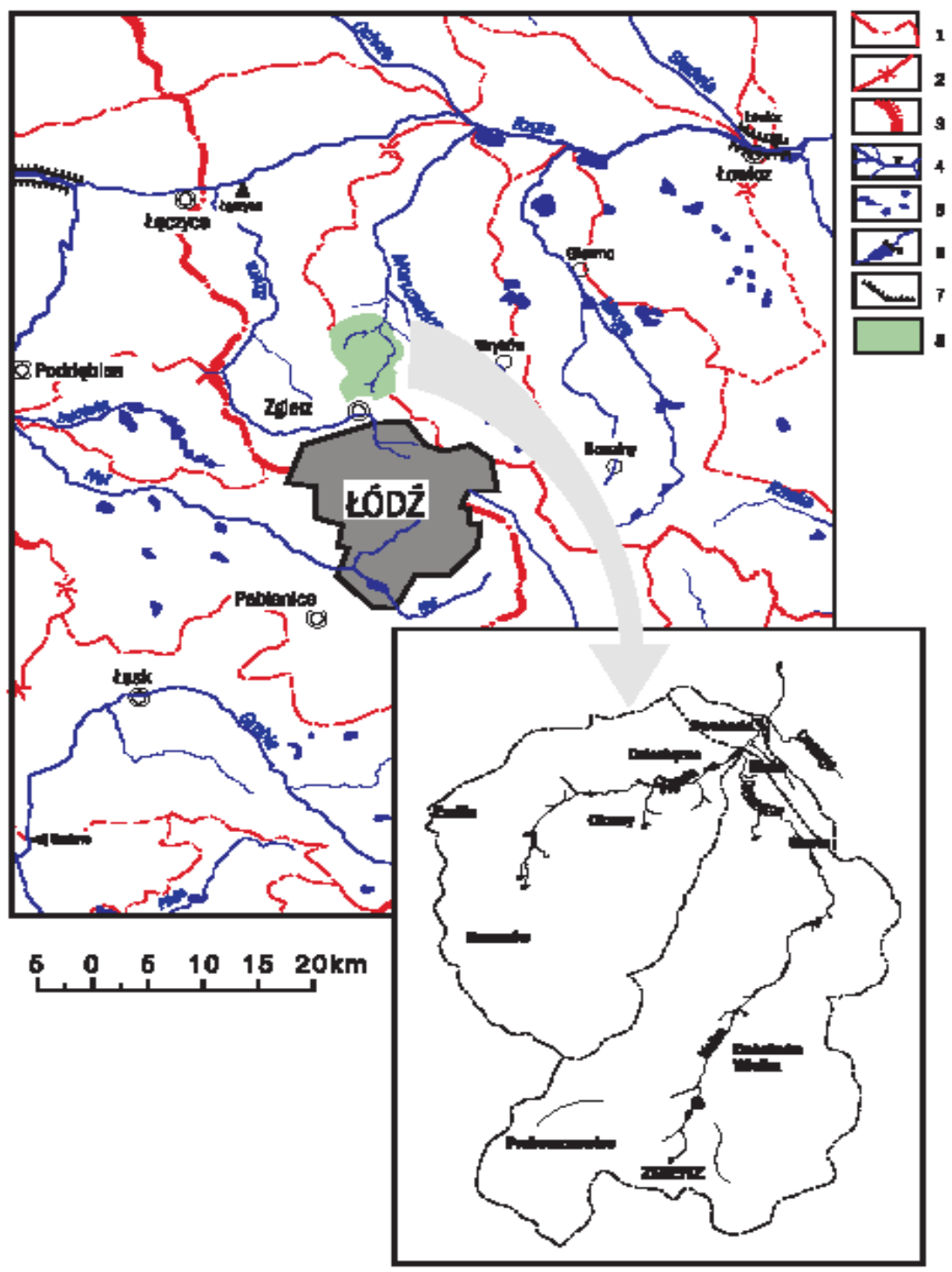

Rys. 1. Lokalizacja zlewni Dzierżąznej

Objaśnienia: 1 -działy wodne; 2 - brama w dziale wodnym; 3 -dział wodny niepewny; 4 - rzeki i wodowskazy; 5 - stawy; 6 - zbiorniki wodne (a - zapory); 7 - obwałowania i groble; 8 - zlewnia badawcza KHiGW UŁ

Fig. 1. The Dzierżązna drainage basin localization

1 - the watersheds; 2 - gap in watershed; 3 - uncertain watershed; 4 - rivers and watergauges; 5 - fishponds and lakes; 6 - artificial lakes and dams; 7 - river dams;

8 - Dzierżązna experimental drainage basin 
źródeł oraz stanu wód podziemnych i ich własności fizykochemicznych), a także warunków pogodowych (automatyczna stacja meteorologiczna). Materiał ten został wykorzystany $\mathrm{w}$ wielu już opracowaniach i analizach. Bibliografię tę łatwo Czytelnik odnajdzie na stronie internetowej KHiGW UŁ (http://hydro. geo.uni.lodz.pl).

Celem tego opracowania jest możliwe spójne i krótkie zaprezentowanie kilku cech fizycznogeograficznych badanego obszaru i prawidłowości dostrzeżonych w toku różnego rodzaju prac badawczych tam prowadzonych, które w istotny sposób modelują lokalny sposób obiegu wody oraz strukturę bilansu wodnego. W ocenie autora wiele zamieszczonych uwag i wniosków ma charakter na tyle ogólny, że mogą być przydatne przy interpretacji wyników podobnych badań na innych obszarach.

\section{Kształtowanie odpływu}

\section{Uwagi wstępne}

Budowa geologiczna i rzeźba terenu są nieodłącznymi elementami środowiska geograficznego, a wiedza o nich winna być zawsze podstawą kształtowania strategii ochrony krajobrazu i przez to stanowić ważny element polityki ekorozwoju. Tworzą one razem swoiste tło, na którym rozgrywają się inne procesy przyrodnicze i antropogeniczne. Jest to jednak tło specyficzne, bo posiadające ważną właściwość. Otóż w wyniku działania różnych procesów zmienia ono ciągle swój charakter, ewoluując razem z nimi. Ukształtowanie rzeźby regionu łódzkiego, w tym obszaru zlewni Dzierżąznej, jest efektem zdarzeń i procesów zachodzących tu od początku plejstocenu, a w szczególności od zlodowacenia warty. Formy rzeźby glacjalnej zostały następnie przemodelowane $\mathrm{w}$ warunkach interglacjalnych, peryglacjalnych i holoceńskich - mają więc charakter poligenetyczny (rys. 2).

\section{Formy i rzeźba terenu}

Rzeźba terenu jest w zlewni Dzierżąznej bardzo urozmaicona, choć wyraźnie rysują się różnice między obiema zlewniami cząstkowymi. Dobrze to oddaje zaprezentowana niżej mapa spadków i kierunków potencjalnego spływu wód powierzchniowych (rys. 3). Punkt o maksymalnej rzędnej znajduje się na południowo-wschodnim fragmencie działu wodnego między Zgierzem a Maciejowem (215,5 m n.p.m.). Wysokość minimalna, występuje zaś w korycie Dzierżąznej, w przekroju wodowskazowym położonym w miejscowości Swoboda około 129,8 m n.p.m. Zatem deniwelacja, na stosunkowo krótkim odcinku (ok. $8 \mathrm{~km}$ ), wynosi ponad $85 \mathrm{~m}$. Daje to spadek wysokości bliski $10 \mathrm{~m} \cdot \mathrm{km}^{-1}$. Tego rzędu wartości nie są zbyt często spotykane w niżowej części Polski, choć w strefie krawędziowej Wzniesień Łódzkich można je uznać niemal za typowe. 


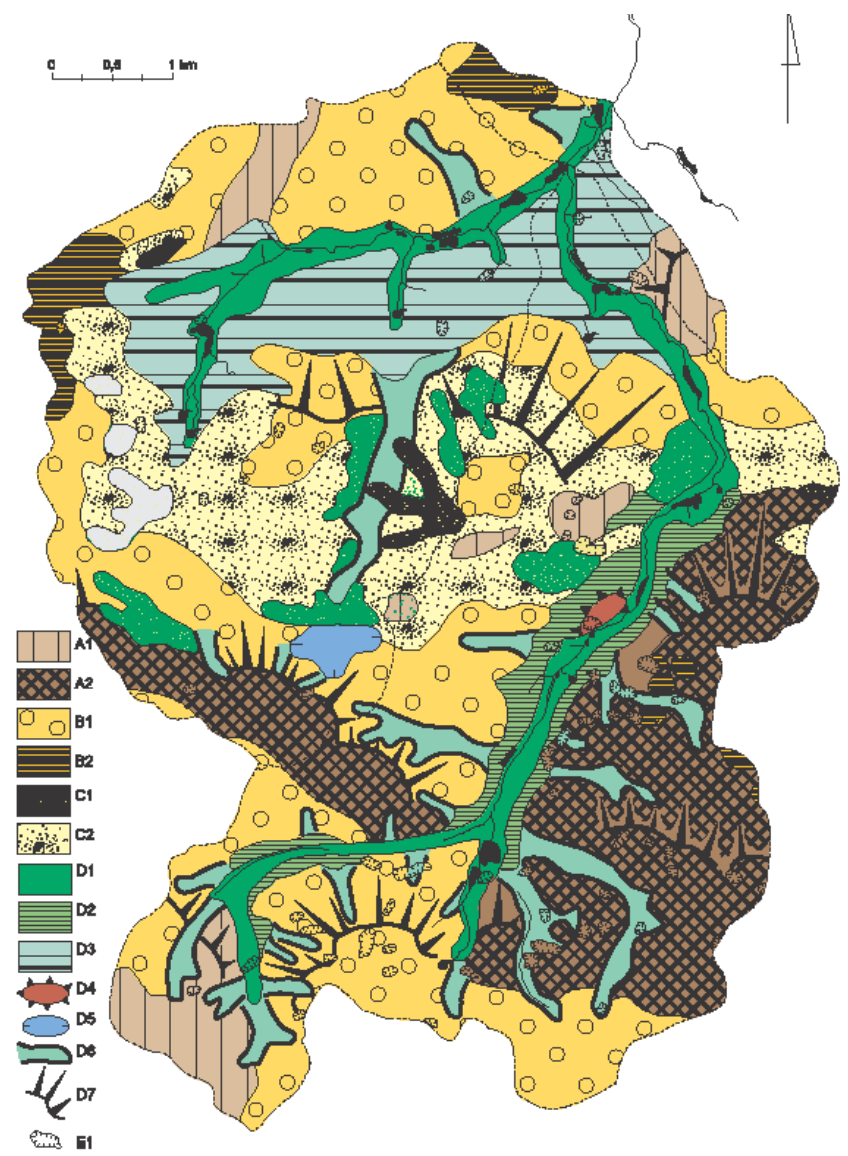

Rys. 2. Formy rzeźby w zlewni Dzierżąznej

Objaśnienia: Formy akumulacji lodowcowej: A1 - wysoczyzna morenowa płaska, A2 - wzgórza moren spiętrzonych; Formy akumulacji wodnolodowcowej: B1 - równiny sandrowe, B2 - kemy; Formy akumulacji eolicznej: C1 - wydmy, C2 - równiny eoliczne; Inne formy akumulacyjne i erozyjne: D1 - dna dolin rzecznych, D2 - rzeczne terasy akumulacyjne, D3 - równiny rozlewiskowo-jeziorne, D4 - ostańce erozyjne,

D5 - zagłębienia po martwym lodzie, D6 - suche doliny i dolinki denudacyjne,

D7 - krawędzie stokowe; Formy antropogeniczne: E1 - wyrobiska (żwirownie, piaskownie, glinianki)

Fig. 2. The relief forms in the Dzierżązna drainage basin

Forms of glacial accumulation: A1 - flat moraine plateau, A2 - push moraine hills; Forms of fluvioglacial accumulation: B1 - outwash plains, B2 - kames; Forms of eolian accumulation: $\mathrm{C} 1$ - dunes, $\mathrm{C} 2$ - eolian plains; Other accumulation and erosion forms: D1 - river valley - floors, D2 - fluvial accumulation terraces, D3 - flooding and lake plains, D4 - residual hills, D5 - dead ice hollows, D6 - dry valleys and denudation valleys, D7 - scarps and slopes; Anthropogenic forms: E1 - pits (gravel pits, sand pits, clay pits) 


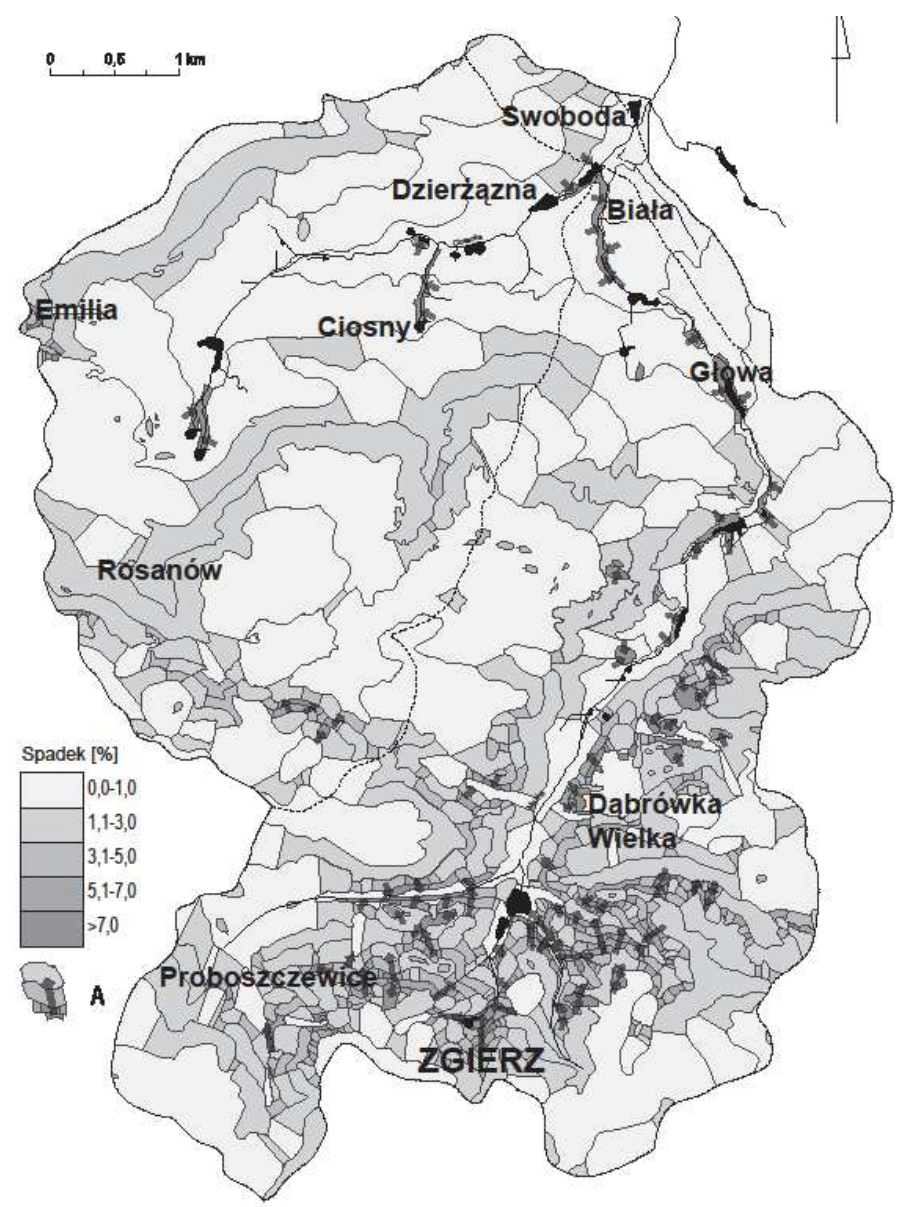

Rys. 3. Lokalne spadki terenu i kierunki potencjalnego spływu wód powierzchniowych w zlewni Dzierżąznej

A - kierunki potencjalnego spływu powierzchniowego

Fig. 3. Local slope and overland flow direction in the Dzierżązna drainage basin A - directions of potential overland flow

W odniesieniu do morfologii terenu wyraźnie zarysowane są różnice między obiema zlewniami cząstkowymi. Zdecydowanie bardziej urozmaicona rzeźba występuje w zlewni cząstkowej Dzierżąznej. Dotyczy to zarówno deniwelacji, jak i lokalnych nachyleń terenu. Dość wspomnieć, że deniwelacja na jej obszarze jest o ok. $25 \mathrm{~m}$ większa niż w zlewni Ciosenki. Można wysunąć też tezę, że w cząstkowej zlewni Dzierżąznej dominuje raczej żywa rzeźba o charakterze erozyjnym, zaś w zlewni Ciosenki większą rolę odgrywają równiny akumulacyjne. 
Średnia wysokość zlewni Dzierżąznej, obliczona przy wykorzystaniu krzywej hipsograficznej, wynosi 166 m n.p.m. Spośród dwu zlewni cząstkowych niżej położona jest powierzchnia odwadniana przez Ciosenkę (średnio o ok. 20m). Również koryta cieków tej zlewni znajdują się przeciętnie o 14 m niżej niż sieć rzeczna Dzierżąznej (Ciosenka - 140,7 m n.p.m., Dzierżązna - 154,7 m n.p.m.). Natomiast w całej zlewni koryta leżą średnio o ok. $18 \mathrm{~m}$ niżej od otaczających je wysoczyzn (148 m n.p.m.). Liczby te dają pogląd na miąższość strefy aktywnej wymiany na tym obszarze oraz informują o jej potencjalnej objętości. Charakterystyki te obliczono stosując rozwiązanie opublikowane w pracy autora (Jokiel 1999). Należy podkreślić, że różnica między średnią wysokością zlewni i średnią rzędną koryt systemu jest w przypadku Ciosenki nieco mniejsza od $15 \mathrm{~m}$, zaś w zlewni cząstkowej Dzierżąznej przekracza $20 \mathrm{~m}$. Zatem miąższość drenowanego profilu czwartorzędu jest $\mathrm{w}$ tej ostatniej o prawie $30 \%$ większa. Gdyby założyć identyczną strukturę geologiczną i hydrogeologiczną obu zlewni cząstkowych, w tym podobny udział frakcji piaszczysto-żwirowej w drenowanym profilu czwartorzędu, to większe zasoby wodne winna gromadzić znacznie „grubsza”, strefa retencji czynnej zlewni Dzierżąznej.

Średni spadek całej zlewni obliczony wzorem Kajetanowicza wynosi 1,3\%, z tym że nachylenia w zlewni Dzierżąznej są przeciętnie o $0,3 \%$ większe niż w zlewni Ciosenki. Również wskaźnik urzeźbienia ma tu większą wartość (Dzierżązna - 9,5; Ciosenka - 8,2). Przeciętna dla całego obszaru wynosi $9,2 \mathrm{~m} \cdot \mathrm{km}^{-1}$. Wartości maksymalne, sięgające $9 \mathrm{~m} \cdot \mathrm{km}^{-1}$, występują w jego południowej części, szczególnie w strefach bezpośrednio przylegających do doliny Dzierżąznej. Warto też zauważyć, że obszary wododziałowe charakteryzują się często znacznie mniejszymi nachyleniami niż tereny położone „wewnątrz” zlewni. Linia łącząca Rosanów Górny, Dąbrówkę Strumiany i biegnąca niemal równoleżnikowo w kierunku Szczawina (poza zlewnią), dzieli cały ten obszar na dwie wyraźnie różniące się części. Na północ od niej dominują tereny płaskie o nachyleniach do $3 \%$ i małych deniwelacjach. Natomiast w części południowej lokalne spadki terenu są znacznie większe, a rzeźba ma charakter pagórkowaty, z mocno zaznaczonymi wzgórzami morenowymi, dolinami rzecznymi i krawędziami erozyjno-denudacyjnymi.

Lokalne nachylenia terenu w obu zlewniach cząstkowych różnią się bardzo wyraźnie. Na obszarach odwadnianych przez Ciosenkę rzadko przekraczają $3 \%$. Dominują tu tereny o spadkach z przedziału: $1,1-3,0 \%$, a więc płaskie równiny akumulacyjne. Stwarza to doskonałe warunki do infiltracji wód opadowych oraz sprzyja powstawaniu zasobnych zbiorników wód podziemnych i formowaniu się odpływu podziemnego.

W zlewni Dzierżąznej, a zwłaszcza w jej południowej części, rzeźba ma zdecydowanie inny charakter. Dość często, lokalne nachylenia są większe od $5,0 \%$ i co ważne, dotyczy to zwykle stoków dolin oraz obszarów bezpośrednio do nich przylegających, a więc stref, gdzie najczęściej pojawia się spływ 
powierzchniowy (obszary zasilania). W oczywisty sposób sprzyja to formowaniu się, w tej części zlewni, odpływu podpowierzchniowego, a na zboczach dolin nawet spływu powierzchniowego. Ich efektem może być z kolei proces spłukiwania i towarzysząca mu erozja gleb na stokach. Układ taki generuje także szybką, powierzchniową migrację i spływ do rzeki zanieczyszczeń oraz różnego rodzaju biogenów, powstających w warunkach rozproszonej zabudowy wiejskiej i braku kanalizacji. To zaś istotnie wpływa zarówno na jakość wody w rzece, jej życie biologiczne, jak i na stan stref buforowych cieku - ekotonów. Natomiast warunki infiltracyjne są w tej części zlewni znacznie gorsze, co w oczywisty sposób nie sprzyja formowaniu się tu znaczących zasobów wód podziemnych w strefie aktywnej wymiany. Warto jednak podkreślić, iż w strefach wododziałowych warunki infiltracji wód opadowych są, z punktu widzenia rzeźby, lepsze niż wewnątrz jej obszaru. Może to mieć istotne znaczenie dla dynamiki wód i odpływu podziemnego.

\section{Budowa geologiczna i przepuszczalność osadów}

Ilościowy opis cech budowy geologicznej podłoża, w tym jego wodoprzepuszczalności jest zadaniem trudnym, złożonym i wymagającym szczegółowych badań terenowych i laboratoryjnych. W badaniach hydrologicznych i hydrogeologicznych parametryzuje się najczęściej: przepuszczalność, odsączalność oraz pojemność wodną i możliwości retencyjne osadów. Warto w tym miejscu podkreślić, że wydajność procesu infiltracji zależy nie tylko od charakteru i parametrów filtracyjnych gleby, ale też od czasu kontaktu wody z jej powierzchnią.

Zlewnię Dzierżąznej w całości pokrywa mozaika osadów czwartorzędowych. Ich litologia i geneza, obok ogromnej, poziomej zmienności przestrzennej charakteryzuje się także dużą różnorodnością w układzie pionowym. W poziomie oraz w pionie ,sąsiadują" więc tu z sobą utwory o bardzo zróżnicowanych parametrach geofiltracyjnych i geostrukturalnych. Dowody na potwierdzenie tej tezy znajdziemy łatwo przeglądając mapy i przekroje geologiczne wykonane dla tego terenu (Klatkowa 1972, 1993).

Duża zmienność budowy geologicznej sprawia, że warunki infiltracji opadów atmosferycznych, tempo przesączania się wody przez warstwę aeracji, a także jej przepływ przez warstwę saturacji, są przestrzennie bardzo zróżnicowane. Należy przy tym podkreślić, że tak jak jakość łańcucha zależy od trwałości jego najsłabszego ogniwa, tak o prędkości i wydajności procesów: infiltracji, filtracji i drenażu decyduje zwykle warstwa o najgorszych parametrach filtracyjnych. Zatem nawet wstępny podział opadu atmosferycznego determinowany jest nie tylko litologią i strukturą osadów znajdujących się na powierzchni, ale również sposobem wykształcenia utworów położonych niżej. Warto w tym miejscu też dodać, że litologia utworów powierzchniowych decyduje nie tylko o tempie i ilości wody przedostającej się do zbiorników wód podziemnych oraz o odpływie podziemnym, ale wpływa także na charakter, głębokość i prędkość odpływu podpowierzchniowego, a więc jednej z form odpływu bezpośredniego. Dotyczy 
to w szczególności stref przylegających do koryt i dolin i to nie tylko cieków stałych, ale także strug okresowych i epizodycznych.

Do oceny przepuszczalności lub nieprzepuszczalności podłoża w skali zlewni stosuje się różnego rodzaju empiryczne współczynniki. Określa się je różnymi metodami, w tym laboratoryjnymi, dla konkretnych osadów lub gleb, przy uwzględnieniu zarówno ich przewodności hydraulicznej, jak i genezy i położenia morfologicznego. Przykładem jest tu współczynnik spływu powierzchniowego $B$ zaproponowany przez $\mathrm{H}$. Czarnecką (1986). Bazuje on na tzw. wskaźniku nieprzepuszczalności gleb Bołdakowa i pokazuje, jaka część opadu atmosferycznego przedostanie się do rzeki na drodze spływu powierzchniowego (zdaniem autora: odpływu bezpośredniego). Jego dopełnienie można zaś uznać za miarę przeciętnej infiltracji efektywnej.

Wartość współczynnika $B$ zawiera się w przedziale od 0,85 (dla gleb wytworzonych na zwietrzelinie silnie ilastej, położonych na stokach górskich) do 0,1 (dla gleb powstałych na luźnych piaskach i żwirach, położonych na obszarach nizinnych). Przeciętny współczynnik odpływu bezpośredniego dla dowolnego obszaru uzyskujemy, obliczając średni ważony współczynnik $B$, przy czym wagami są powierzchnie zajęte przez osady o określonym współczynniku.

Obraz przestrzennej zmienności współczynnika $B$ prezentuje mapa wykonana w konwencji rastrowej (rys. 4). Średni współczynnik nieprzepuszczalności w danym oczku siatki obliczono tu jako średnią ważoną. Wagami były oczywiście udziały procentowe pól o określonej wielkości współczynnika $B$. Dość łatwo można na tej mapie dostrzec, iż przeciętne możliwości infiltracyjne osadów, warunkowane ich litologią, są znacznie lepsze w zlewni Ciosenki (średnio: $B=0,24)$, niż w cząstkowej zlewni Dzierżąznej $(B=0,31)$. Ilość infiltrujących wód opadowych jest w tej ostatniej dużo większa, a odbywa się to oczywiście „kosztem” odpływu bezpośredniego. Średnia dla całej zlewni wynosi 0,28.

Z punktu widzenia zachowania walorów środowiska na tym terenie, jak też prawidłowej gospodarki wodnej, dobre warunki infiltracyjne są zjawiskiem pozytywnym. Woda zatrzymywana jest bowiem w strefie aktywnej wymiany na dłużej i przez to może być lepiej wykorzystana i to zarówno w toku procesów naturalnych, jak też w lokalnej gospodarce wodnej. Równocześnie procesy infiltracji i przepływu podziemnego (jak pamiętamy na stosunkowo długim odcinku) prowadzą do istotnego samooczyszczania i dezaktywacji pojawiających się tu zanieczyszczeń. W efekcie wody podziemne drenowane przez Ciosenkę potencjalnie powinny być czyste i pozbawione zanieczyszczeń obszarowych związanych $\mathrm{z}$ rolnictwem i rekreacją. $\mathrm{Z}$ drugiej jednak strony duża wodoprzepuszczalność powierzchni (zwłaszcza sandru grotnicko-lućmierskiego) i brak izolacji strefy saturacji stwarza poważne zagrożenia, gdy idzie o możliwość zanieczyszczenia wód podziemnych tej zlewni cząstkowej. Dotyczy to zwłaszcza części środkowej obszaru, przez który przebiega nitka autostrady A2. Droga oraz towarzyszące jej obiekty (np. stacje benzynowe) są 
dziś poważnym emitorem zanieczyszczeń: płynnych, pyłowych i gazowych (Moniewski, Stolarska 2008; Moniewski, Tomalski 2008; Bartnik, Moniewski 2012). Długotrwała ekspozycja gleb na imisję tego rodzaju zanieczyszczeń wywoła niewątpliwe kumulację w nich różnych substancji, a w efekcie przyczyni się do zmian składu chemicznego i jakości płytkich wód podziemnych występujących na tym terenie. Istotnym zagrożeniem jest także odwadnianie autostrady, a przez to spłukiwanie $\mathrm{z}$ niej i odprowadzanie do cieków lub bezpośrednio na pola różnych, aktywnych substancji chemicznych. Zbudowane systemy podczyszczające (baseny, rowy infiltracyjne, systemy rozprowadzające) nie są w stanie w pełni zabezpieczyć środowiska przed skażeniem (Moniewski i in. 2007).

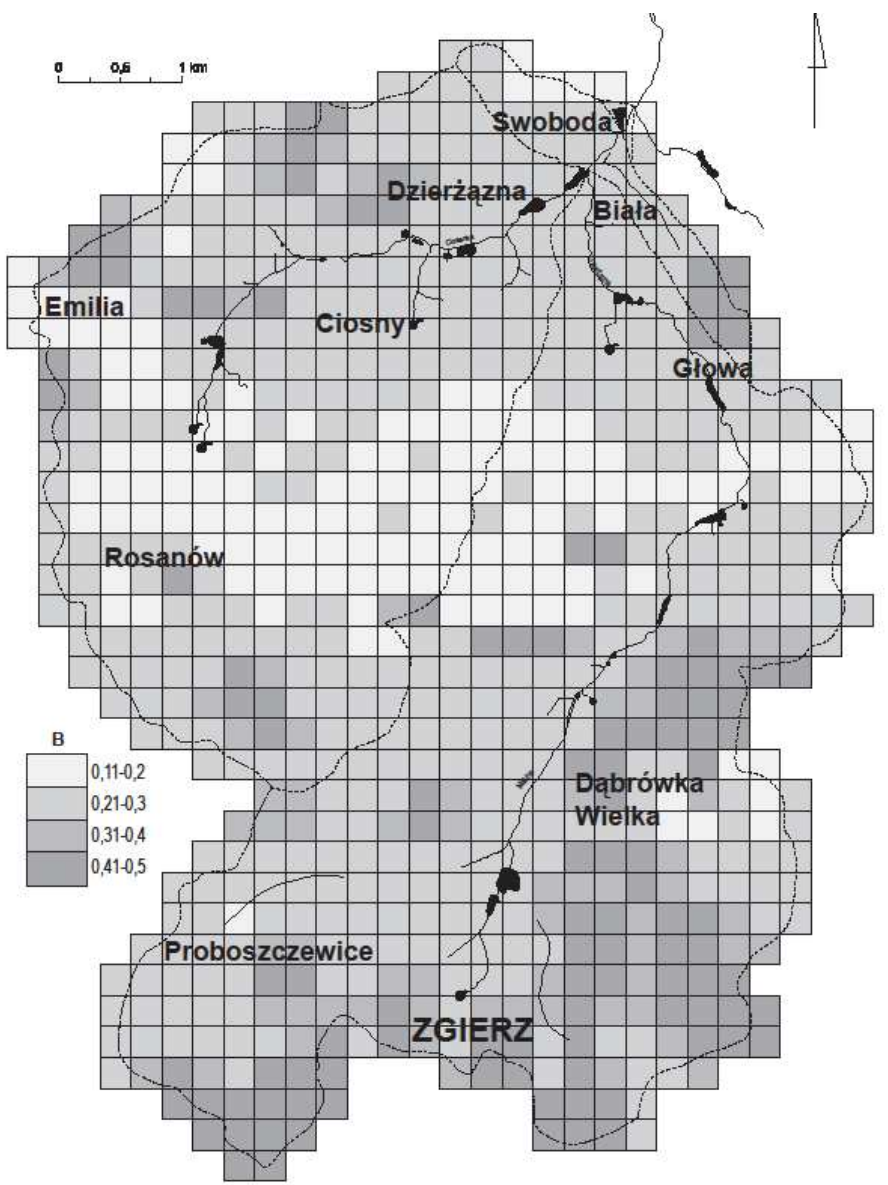

Rys. 4. Wskaźnik nieprzepuszczalności strefy aeracji $B$ (metoda Bołdakowa)

Fig. 4. Water permeability of surface deposits in the Dzierżązna drainage basin Boldakov index 
Należy też podkreślić, że niektóre tereny w zlewni Ciosenki, a zwłaszcza obszary pokryte bardzo dobrze przepuszczalnymi, miąższymi piaskami (często przewianymi lub tworzącymi wydmy), są dziś intensywnie wykorzystywane rekreacyjnie - np. kompleks działek letniskowych Rosanowa, Ciosen i Emilii. Prawie wszystkie domki letniskowe oprócz studni posiadają również szamba (najczęściej chłonne), do których odprowadzane są nieczystości. Ponadto większość wiejskich piaskowni, żwirowni, wyrobisk oraz śródleśnych i śródpolnych obniżeń terenu zasypywana jest odpadkami stałymi. Ich ilość bardzo szybko rośnie wraz z rozwojem osiedli letniskowych (Jokiel 2002). Oba te zjawiska, w powiązaniu z dobrą przepuszczalnością utworów pokrywowych, stwarzają istotne zagrożenie dla stanu czystości lokalnych poziomów wodonośnych oraz całego środowiska. Zważywszy też, że znaczna część zlewni Ciosenki wchodzi w skład strefy ONO (Obszar Najwyższej Ochrony), wyznaczonej dla poziomów wodonośnych kredowej niecki łódzkiej oraz uwzględniając możliwość przenikania do tych poziomów niektórych zanieczyszczeń przez istniejące tu okna hydrogeologiczne, konieczne jest ścisłe przestrzeganie ograniczeń przewidzianych dla tej strefy i stały monitoring stanu czystości wód powierzchniowych i podziemnych na całym jej obszarze.

Wiadomo, że w procesie formowania się odpływu powierzchniowego, a nawet podpowierzchniowego, bardzo istotną rolę odgrywa infiltracja przesunięta. Słowo ,przesunięta" odnosi się przy tym zarówno do przesunięcia w czasie (proces wsiąkania wody jest opóźniony w stosunku do momentu zasilania $\mathrm{w}$ wodę powierzchni terenu), jak i do przesunięcia $\mathrm{w}$ przestrzeni (infiltracja zachodzi często w innym miejscu stoku niż punkt, na który spada opad, przy czym drogę między tym punktem a miejscem infiltracji woda pokonuje $\mathrm{w}$ formie spływu powierzchniowego lub podpowierzchniowego). Równocześnie odpływem bezpośrednim nazywamy sumę spływu powierzchniowego i podpowierzchniowego, które uformowały się w danym czasie na całym obszarze zlewni. Część tego odpływu nigdy jednak, w tej formie, nie dotrze do koryt systemu. Przeszkodą będzie tu oczywiście infiltracja przesunięta. Zatem efektywny odpływ bezpośredni jest tylko częścią tego odpływu - częścią, która dociera do koryt w postaci spływu powierzchniowego i podpowierzchniowego. Jego objętość będzie więc uzależniona nie tylko od rodzaju i nachylenia powierzchni spływu, ale także od odległości od cieków, czyli od drogi jaką musi pokonać uformowany „wyżej” odpływ bezpośredni. Infiltrująca woda, będąca różnicą bilansową między odpływem bezpośrednim i efektywnym odpływem bezpośrednim zasili natomiast strefę saturacji.

Spostrzeżenie to legło u podstawy konstrukcji mapy rastrowej, prezentującej podatność terenu na formowanie się efektywnego odpływu bezpośredniego (rys. 5). Przy jej konstrukcji wykorzystano mapę współczynnika nieprzepusz- 
czalności (rys. 4) oraz dwa inne, nie prezentowane tu opracowania kartograficzne: mapę średnich nachyleń oraz mapę ekwidystant odległości od wody (Jokiel 2002).

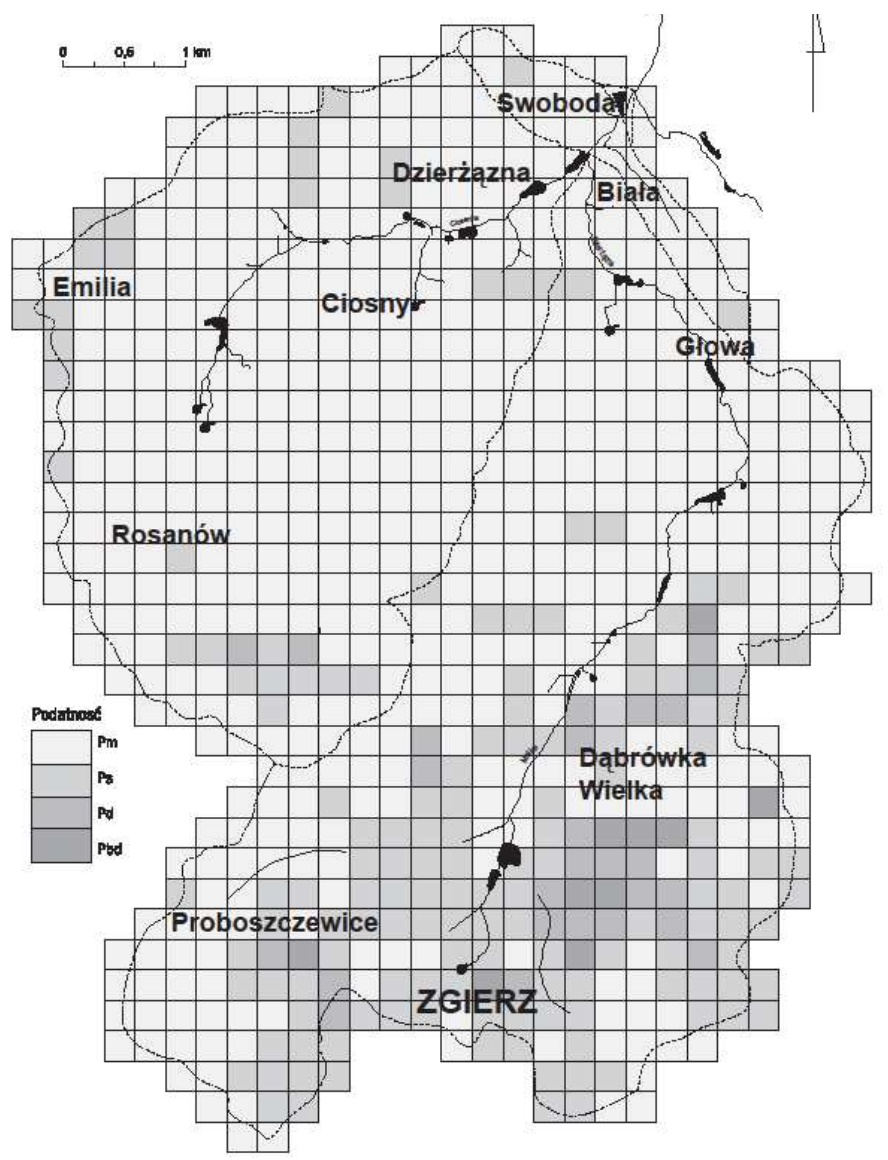

Rys. 5. Podatność terenu na formowanie się spływu powierzchniowego w zlewni Dzierżąznej

Pm - podatność mała; Ps - podatność średnia; Pd - podatność duża; Pbd - podatność bardzo duża

Fig. 5. Possibility of surface and subsurface runoff in the Dzierżązna drainage basin Pm - low; Ps - medium; Pd - high; Pbd - very high

Mapę podatności na formowanie się odpływu bezpośredniego konstruowano w dwu etapach. W pierwszym, na podstawie średnich nachyleń i współczynnika nieprzepuszczalności, ocenie poddano potencjalną możliwość powstania szybkich form odpływu. Wykorzystano do tego zarówno własne obserwacje terenowe, jak i bogatą, choć rozproszoną literaturę. W następnym kroku podjęto próbę 
oceny efektywności powstających tam, szybkich form odpływu. Przyjęto założenie, że im bliżej sieci wód powierzchniowych znajduje się dany obszar, tym „szanse” na bezpośrednie jej zasilanie, powstałymi tam, szybkimi formami spływu, są coraz większe. Szczegóły metodyczne znajdzie czytelnik w pracy autora (2002).

Wynikiem tej procedury jest cytowana już wyżej mapa. W sposób uproszczony, subiektywny, ale przecież czytelny, wskazuje obszary, gdzie szanse na uformowanie i ,przetrwanie" obu form odpływu bezpośredniego są duże, oraz tereny, z których odpływ ten nigdy w sposób znaczący nie zasili koryt cieków. Warto zauważyć, że pierwszy rodzaj powierzchni spotykany jest dość rzadko i to głównie w górnej części zlewni Dzierżąznej. Szczególnie predysponowane są tutaj prawie bezleśne, ale równocześnie zabudowane i zagospodarowane tereny, położone we wschodniej części tego obszaru. Konieczne wydaje się więc utrzymanie, a tam gdzie ich nie ma - utworzenie aktywnych stref buforowych, ograniczających spływ i migrację różnych zanieczyszczeń z tych terenów do koryta Dzierżąznej. Jak wiadomo, rolę taką dobrze spełniają 80-90. metrowe pasy łąk dolinnych. Ograniczają one niemal do minimum spływ fosforu do cieków (Ryszkowski 1994). Natomiast tereny, na których szybkie formy odpływu mogą wystąpić jedynie sporadycznie, a i wówczas będą one miały małą szansę by dotrzeć bezpośrednio do cieków, spotkamy w zlewni Ciosenki. Warto podkreślić, że nawet $\mathrm{w}$ strefie krawędzi doliny tej rzeki, prawdopodobieństwo wystąpienia efektywnego spływu powierzchniowego jest nikłe.

Spostrzeżenia te można $\mathrm{z}$ powodzeniem wykorzystać przy ocenach roli poszczególnych fragmentów zlewni $\mathrm{w}$ formowaniu różnych form odpływu, w analizach zasobności wodnej obszaru oraz w planach przestrzennego zagospodarowania gruntów i przy projektach ich rekultywacji. Zauważmy, że obszary o dużym i efektywnym odpływie bezpośrednim są zawsze potencjalnym ogniskiem zanieczyszczeń wód powierzchniowych. Istniejące tam, powierzchniowe lub płytko zagrzebane składowiska odpadów, wylewiska nieczystości, bądź inne niezorganizowane ogniska ścieków, są intensywnie przemywane przez powstające szybkie formy odpływu, a wypłukiwane $\mathrm{z}$ nich substancje łatwo docierają do cieków oraz do otaczających je stref ekotonowych. Groźne dla stanu czystości wód powierzchniowych na tych obszarach mogą być także dzikie zrzuty ścieków bytowych z pojedynczych gospodarstw i zmywy nieczystości z utwardzonych terenów przemysłowych i gęsto zabudowanych. Dotyczy to w szczególności rejonu „Gór Wilamowskich” i Rozalinowa, Proboszczewic, Dąbrówki Wielkiej, Dąbrówki Strumiany, a w zlewni Ciosenki okolic Rosanowa Górnego.

\section{Opad i intercepcja}

Położenie zlewni Dzierżąznej w strefie krawędziowej Wzniesień Łódzkich, żywa rzeźba oraz duże deniwelacje sprawiają, że wysokość opadów atmosferycznych wykazuje w niej znaczne zróżnicowanie przestrzenne. W celu jego identyfikacji i dla prawidłowej oceny przeciętnych sum opadowych w zlewni, 
opracowano model pozwalający określać miesięczny wskaźnik opadu w poszczególnych polach siatki, przy uwzględnieniu odpowiedniego systemu równań oraz danych z posterunku opadowego w Ciosnach (Jokiel 2002). Model ten ma charakter regresyjny. Składa się nań system 12 równań liniowych uzależniających sumy opadu w poszczególnych miesiącach od rzędnej terenu oraz równania transformującego punktowo mierzony opad na cały obszar zlewni. Sumy miesięczne opadu były następnie korygowane przy użyciu poprawek zaproponowanych przez Kowalczyk i Ujdę (Byczkowski 1996). Dla każdego oczka siatki, uzyskiwano w ten sposób miesięczne i roczne wskaźniki opadów skorygowanych (rys. 6).

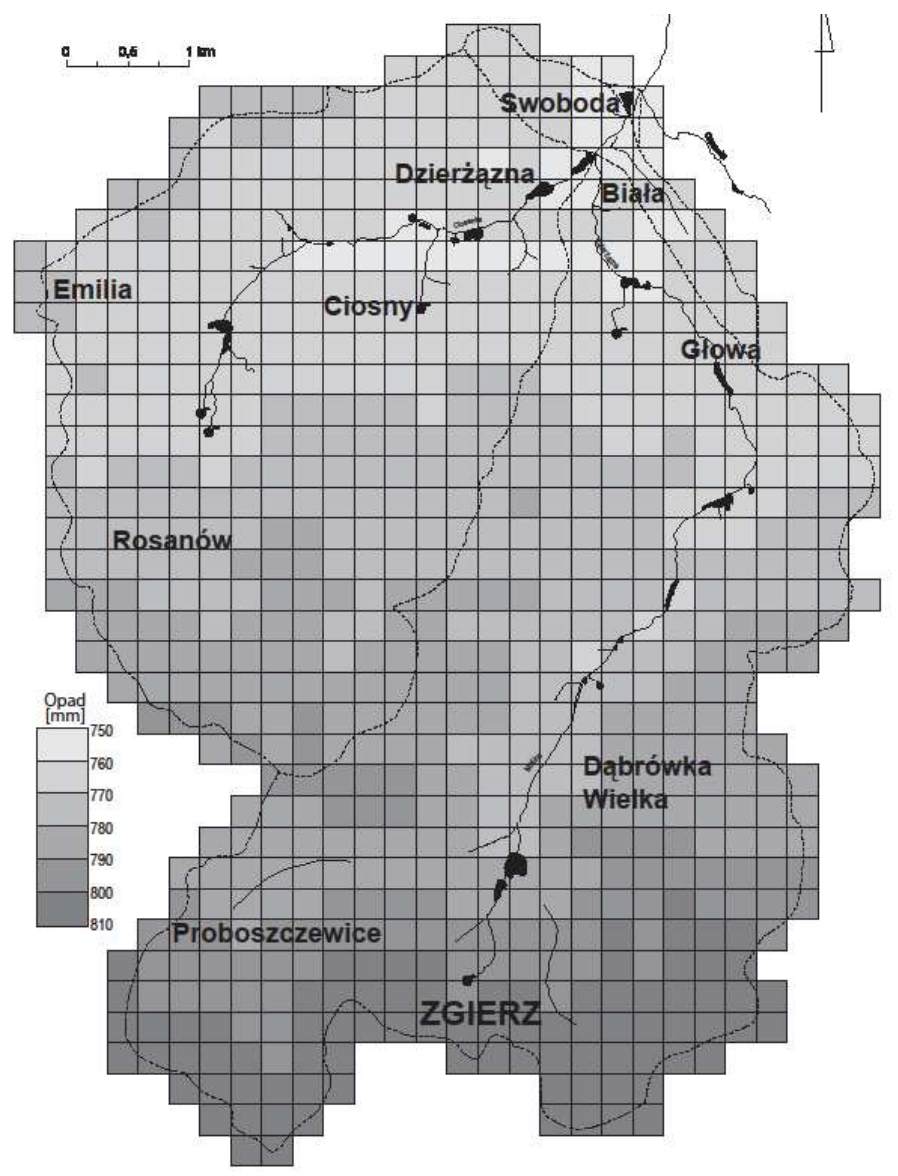

Rys. 6. Przestrzenne zróżnicowanie sum skorygowanego opadu rocznego [mm] w zlewni Dzierżąznej w $2001 \mathrm{r}$.

Fig. 6. Spatial distribution of annual sum of precipitation [mm] in the Dzierżązna drainage basin in 2001 
Średnia roczna suma opadu zmierzonego na posterunku w Ciosnach w latach 1999-2010 wyniosła $611 \mathrm{~mm}$. Uwilgotnienie w tym okresie było więc zbliżone do przeciętnego dla tej części obszaru podłódzkiego, przy czym rok 2001 był wilgotny $(764 \mathrm{~mm})$, zaś rok 2003 bardzo suchy $(467 \mathrm{~mm})$. Roczne sumy opadów skorygowanych poprawką Kowalczyk i Ujdy były średnio o 71,7 mm wyższe od zmierzonych, przy czym roczne poprawki wynosiły od 50 do $83,6 \mathrm{~mm}$. Po ich uwzględnieniu średnia roczna suma opadu skorygowanego wynosiła $673 \mathrm{~mm}$, a wszystkie sumy roczne mieściły się w przedziale $517-847 \mathrm{~mm}$.

Średni roczny współczynnik zaśnieżenia (udział opadów śnieżnych w sumie rocznej) wynosił $14,6 \%$, przy czym był bardzo zróżnicowany w wieloleciu. Maksymalnie 35\% wody spadło $\mathrm{w}$ postaci śniegu (2006), minimalnie 4,4\% (1999). Tylko w ciągu dwu zim $(2005,2006)$ opady śnieżne były większe od $100 \mathrm{~mm}$, a w jednym roku (1999) mniejsze od $35 \mathrm{~mm}$ (Siudek 2012).

Ugór zużywa na parowanie tylko 55\% energii słonecznej, a $40 \%$ kierowane jest na ogrzanie otaczającego go powietrza. Las natomiast, prawie $90 \%$ energii przeznacza na parowanie, a tylko 7\% na ogrzewanie atmosfery. Systemy korzeniowe drzew sięgają głębiej niż korzenie większości roślin uprawnych, stąd więcej wód strefy aeracji, a nawet saturacji znajduje się w ich zasięgu. Obszary zadrzewione, w przeciwieństwie do innych ekosystemów, pochłaniają nie tylko większą ilość energii, ale równocześnie włączają do obiegu dużo większe ilości wody (Jaworski 1986; Kędziora 1995). Tereny leśne transpirują o 22\% wody więcej niż łąki i $34 \%$ więcej niż pola uprawne. W konsekwencji, nie tylko retencyjność obszarów zalesionych i zadrzewionych jest większa niż terenów pozostałych, ale szybsze jest tam również tempo krążenia wody. W ciągu roku, 1 ha lasu, w zależności od gatunku, wieku i wysokości opadów, zużywa na transpirację 1,0-3,5 $\mathrm{mln} \mathrm{dm}^{3}$ wody, czyli od 100 do $350 \mathrm{~mm}$.

Również intercepcja na terenach leśnych jest zjawiskiem istotnym. Przeciętnie, w ciągu roku las zatrzymuje i zwraca do atmosfery 100-200 mm opadu, opóźniając i istotnie redukując odpływ. W każdej porze roku las jest magazynem zapasów wilgoci $\mathrm{w}$ wodach podziemnych, glebie oraz w powietrzu, a także w biomasie i na roślinności leśnej (intercepcja). W krajobrazie rolniczym podobną rolę odgrywają pasy zadrzewień śródpolnych, kępy drzew towarzyszące niszom źródłowym i mokradłom oraz roślinność porastająca brzegi cieków (Ryszkowski 1994).

W procesie obiegu wody równie ważne są łąki i nadrzeczne błonia. Opór jaki stawia wodzie płynącej po powierzchni gęsta roślinność trawiasta jest ogromny. W efekcie, spływ powierzchniowy na łąkach, podobnie jak w lesie, zwykle nigdy nie powstaje. Także tempo i wydajność procesu infiltracji opadu na łące są 10 razy większe niż na nagim gruncie i kilka razy większe niż na polu uprawnym. Nadrzeczne błonia są także znaczącymi rezerwuarami nadwyżek wody, zarówno tej pochodzącej z rzeki występującej z brzegów po wiosennych rozto- 
pach, jak i tej, która w okresie intensywnego zasilania, w postaci spływu powierzchniowego i glebowego, dociera z wysoczyzny do doliny rzecznej.

We współczesnym krajobrazie rolniczym struktura przyrodnicza pól uprawnych jest $w$ coraz większym stopniu upraszczana. W strefie podmiejskiej, a w takich warunkach funkcjonuje badana zlewnia, jest nieco inaczej. Pojawia się tu bowiem odmienna od naturalnej, ale dość wyraźnie zaznaczona wtórna różnorodność krajobrazu. Lasy stają się zwykle rzadsze, ale lokalnie mogą też gęstnieć, zarastając roślinnością ruderalną. Miejsce monokultur uprawnych zajmują, nierównomiernie rozłożone poletka warzywne, sady, plantacje, ogródki działkowe i trawniki, przeplatające się z licznymi, czekającymi na zagospodarowanie odłogami oraz porzuconymi ugorami i nieużytkami. Zwiększa się także liczba sztucznych sadzawek i stawów otoczonych pasami zadrzewień. Wymienione formy użytkowania gruntów i antropogenicznego zagospodarowania krajobrazu, przy rozsądnym natężeniu i mozaikowym układzie przestrzennym, zdają się sprzyjać małej retencji i retencji krajobrazowej. Celowa działalność człowieka w strefie podmiejskiej, nie tylko urozmaica jej krajobraz, wprowadzając do niego nowe obiekty, ale równocześnie może wzmacniać, a nawet generować szereg pozytywnych zjawisk i procesów związanych z obiegiem wody i energii.

Intercepcją nazywamy proces chwilowego przechwytywania i zatrzymywania wody opadowej przez różne zbiorowiska roślinne. W wyniku działania tego procesu część opadu zwracana jest do atmosfery wskutek parowania ze zwilżonej powierzchni roślin, a pozostała ilość wody opadowej dociera do gruntu z większym lub mniejszym opóźnieniem. Zjawisko intercepcji zachodzi zarówno latem, jak i zimą, przy czym w chłodnej porze roku opóźnienie jest zwykle większe, a straty intercepcji znacznie mniejsze niż w lecie. Charakter procesu intercepcji sprawia, iż jest on bardzo zmienny w czasie oraz $\mathrm{w}$ przestrzeni (wpływ zmian w charakterze i stopniu zwartości szaty roślinnej). Odgrywa on większą rolę w czasie krótkich ulew, niż w przypadku długotrwałych słot i jest bardzo trudny do pomierzenia i modelowania. Jednocześnie zjawisko to istotnie wpływa na tempo i ilość wody znajdującej się w obiegu, sprzyjając również wymianie energii między szatą roślinną a atmosferą i gruntem.

Wielkość maksymalnej intercepcji, czyli ilość wody jaką potencjalnie jest w stanie przechwycić szata roślinna zlewni, określono na podstawie mapy użytkowania terenu oraz zaadoptowanych z literatury wskaźników pojemności zbiornika intercepcji różnych zbiorowisk roślinnych (Jokiel 2002). Zbiorowiska te podzielono przy tym na ,jednopiętrowe” i ,wielopiętrowe”. Proces zatrzymywania wody może się bowiem odbywać na jednym lub na wielu poziomach, a więc intercepcja może się składać z jednego zbiornika retencji chwilowej (np. intercepcja zbóż), jak i z kaskady takich zbiorników (np. intercepcja lasu). Dla stawów i innych oczek wodnych przyjęto wartość zero. Na podstawie tych wskaźników oraz udziału powierzchni poszczególnych zbiorowisk roślinnych w obrębie każdego poletka elementarnego, obliczono średnią ważoną pojemność 
intercepcji w każdym oczku siatki, uzyskując w efekcie jej przestrzenny obraz w zlewni (rys. 7).

W skali całego, badanego obszaru, pojemność maksymalna wszystkich zbiorników intercepcji jest bliska 2,3 $\mathrm{mm}$. Oznacza to, że w ciepłej porze roku, pierwsze 2,3 mm każdego opadu, który spadnie równomiernie na obszar zlewni, zostanie zatrzymane na roślinności i wróci do atmosfery wskutek ewaporacji.

Mówiąc jeszcze inaczej, pojedynczy opad o wysokości mniejszej niż 2,3 mm nie dotrze do powierzchni gruntu i nie weźmie udziału w dalszym obiegu wody. $\mathrm{W}$ aspekcie przestrzennym zróżnicowanie jest tu oczywiście znacznie większe. Dla obszarów leśnych granicą jest opad o wysokości $5 \mathrm{~mm}$, zaś na ugorach i nieużytkach część opadu przekraczająca zaledwie $0,5 \mathrm{~mm}$ może już pojawić się na powierzchni gruntu.

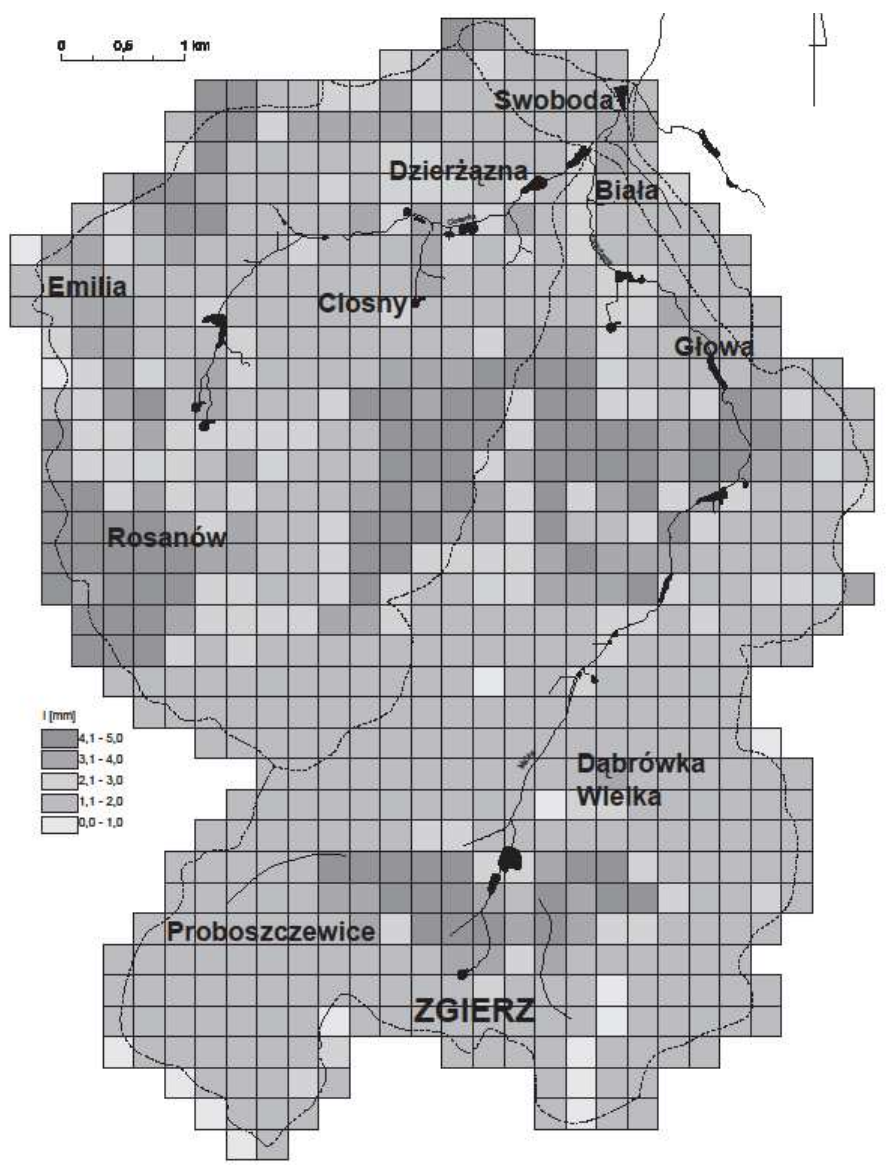

Rys. 7. Intercepcja szaty roślinnej w zlewni Dzierżąznej [mm]

Fig. 7. Interception storage capacity of the vegetation in the Dzierżązna drainage basin $[\mathrm{mm}]$ 
$\mathrm{Z}$ punktu widzenia retencji krajobrazowej i tempa obiegu wody w zlewni Dzierżąznej przestrzenne rozmieszczenie ,pojemności” zbiornika intercepcji jest w niej niezbyt korzystne. Jak pamiętamy, powierzchnie sprzyjające powstawaniu szybkich form odpływu występują głównie w strefach wododziałowych oraz na terenach zabudowanych. Jednocześnie obszary te charakteryzują się stosunkowo małą pojemnością zbiornika intercepcji (rys. 5). Tworzą się tam zatem bardzo sprzyjające warunki do powstawania wielu niekorzystnych zjawisk hydrologicznych i agrohydrologicznych (spływ powierzchniowy, erozja rowkowa, zmywanie zanieczyszczeń, wypłukiwanie z gleb substancji organicznych, zanieczyszczenie i eutrofizacja wód powierzchniowych). Dotyczy to w szczególności południowej części obszaru (Zgierz, Proboszczewice) oraz terenów rolnych wsi Dąbrówka i Dąbrówka Strumiany. Zjawiska te w oczywisty sposób nie sprzyjają zachowaniu dobrych parametrów fizykochemicznych wody w kąpielisku Malinka oraz w źródłowym odcinku Dzierżąznej. Warto przy okazji podkreślić, że wyprostowany i uregulowany odcinek koryta Dzierżąznej poniżej tego kąpieliska niepotrzebnie zwiększa prędkość przepływu wody, skracając jednocześnie czas jej pobytu w obrębie bariery biogeochemicznej, jaką tworzą tu nadrzeczne łąki i szuwary. Osłabia to istotnie proces samooczyszczania i eliminacji zanieczyszczeń z niezbyt przecież czystych wód zrzucanych $\mathrm{z}$ tego stawu. Na dodatek, wody te zanieczyszczane są biogenami na odcinku rzeki biegnącym przez wieś Dąbrówka Strumiany.

Podobną uwagę można sformułować analizując dodatkowo przestrzenny rozkład infiltracji, której estymatorem może być współczynnik nieprzepuszczalności $B$ (rys. 4). Tereny o dużych możliwościach infiltracyjnych położone w zlewni Ciosenki (obszar piasków sandrowych) charakteryzują się jednocześnie dużą pojemnością zbiornika intercepcji (tereny leśne). Wpływa to oczywiście na ograniczenie (zwłaszcza w półroczu letnim) infiltracji, a co za tym idzie wydatnie zmniejsza zasilanie zbiornika wód podziemnych sandru grotnicko-lućmierskiego.

\section{Formowanie retencji}

\section{Uwagi wstępne}

Cyklem hydrologicznym w zlewni nazwiemy rodzaj złożonej i dynamicznej współzależności między obiektami zlewni i procesami hydrologicznymi, jakie w niej działają. W najprostszym ujęciu można go scharakteryzować jako transformację opadu atmosferycznego, stanowiącego wejście do systemu zlewni, który, dzieląc się na różne rodzaje retencji, dąży w efekcie do wyjścia w formie odpływu bezpośredniego i podziemnego oraz parowania terenowego (Soczyńska 1989).

Na wejściu do systemu występuje opad. Dociera on jednocześnie i bezpośrednio tylko do 3 podsystemów: intercepcji, lustra wody w korytach i stawach 
oraz lokalnie do powierzchni gruntu (nagiego). Stąd, wskutek różnych procesów, woda kierowana jest do kolejnych zbiorników. Istotna część opadu wraca także do atmosfery w postaci różnych form parowania terenowego, działających $\mathrm{w}$ różnych podsystemach oraz $\mathrm{w}$ różnych momentach czasowych. Bywa też, że część wody odprowadzana jest poza hydrologicznie czynną strefę danej zlewni retencja apotamiczna. Każdy ze „zbiorników retencyjnych zlewni” może jednak „odrzucić" nadwyżkę kierowanego do niego strumienia opadu. Powstają wówczas mniej lub bardziej trwałe, różnorodne formy odpływu.

Liczba procesów działających $\mathrm{w}$ zlewni, a przede wszystkim ich natężenie i wydajność, zależą nie tylko od sezonu, ale są również funkcją czasu i właściwości fizycznogeograficznych zlewni. Czynnik czasu związany jest przy tym bezpośrednio $\mathrm{z}$ dynamiką procesów hydrologicznych. Upraszczając można przyjąć, że aktualne możliwości retencyjne wszystkich podsystemów zlewni, jak też natężenie wielu procesów hydrologicznych, zależą istotnie od czasu, który minął od momentu wystąpienia zasilania np. opadu. Niektóre z nich działają niemal wyłącznie tuż po opadzie np. skapywanie, spływ powierzchniowy, a z upływem czasu ich natężenie maleje do zera. Ustępują one wówczas miejsca innym np. transpiracji, czy odpływowi podpowierzchniowemu. Jedynie parowanie $\mathrm{z}$ wolnych powierzchni wodnych i odpływ gruntowy są względnie trwałe w czasie, choć i w ich przypadku, w okresach długich posuch, odpływ podziemny może zostać zahamowany, a w trakcie opadu lub mgły parowanie także zbliży się do zera.

Pojemność wodna podsystemów ulega bardzo istotnym zmianom. Zauważmy jednak, że wielkość i charakter tych zmian są funkcją bieżącego stanu retencji w podsystemach. Dotyczy to szczególnie zbiorników, których objętość jest ograniczona. W pełni nasycona wodą (wskutek wcześniejszych opadów) warstwa aeracji, ,odrzuci” niemal w całości każdy impuls opadowy. Mimo „dostawy” nowej wody retencjonowane w niej zapasy niewiele się zmienią. Jednocześnie w okresie suszy glebowej infiltrujący opad może zwiększyć te zasoby nawet o rząd wielkości. Również niski poziom retencji wywołuje istotne „komplikacje” w funkcjonowaniu systemu hydrologicznego zlewni. W czasie suszy glebowej zasoby wody dostępnej dla roślin maleją niemal do zera. To zaś redukuje (czasem także do zera) wydajność procesów transpiracji i przesiąkania. Jednym z efektów jest wówczas spadek retencji wód podziemnych, który może prowadzić do zerwania więzi hydraulicznych koryt z poziomami wodonośnymi, a w konsekwencji do zaniku zasilania podziemnego i wyschnięcia cieków.

Jeśli chodzi o drugi czynnik, tj. warunki fizycznogeograficzne, trzeba podkreślić, że indywidualne cechy zlewni mogą powodować, iż niektóre procesy nie wystąpią w niej nigdy, bądź pojawiać się będą wyłącznie okresowo lub epizodycznie. Dla przykładu: na obszarach pozbawionych zbiorników wód powierzchniowych parowanie $\mathrm{z}$ wolnej powierzchni wodnej będzie małe, a tam gdzie wody podziemne występują bardzo głęboko, mało wydajny będzie także proces 
ich parowania. Także spływ powierzchniowy wystąpi tylko tam, gdzie spadki terenu, słaba przepuszczalność gleb i małe tarcie wywołane roślinnością, pozwolą na przezwyciężenie detencji powierzchniowej. Powstanie lokalnego spływu powierzchniowego (skupionego i rozproszonego) nie oznacza przy tym, że woda $\mathrm{z}$ nich dotrze do koryt cieków. Spływ efektywny będzie bowiem uzależniony dodatkowo od wielkości strat powstających na stoku, w tym od wielkości infiltracji przesuniętej. Te zaś zależą m.in. od odległości, jaka dzieli miejsce uformowania się spływu od koryta cieku.

\section{Retencja sieci hydrograficznej}

Dzierżązna jest pierwszym znaczącym, lewostronnym dopływem Moszczenicy, która od południa zasila Bzurę i wraz z nią łączy się z Wisłą. Jest więc ciekiem IV rzędu. Struga bierze początek z zespołu niewielkich źródeł położonych $\mathrm{w}$ rejonie Rudunek, powyżej piętrzenia w Malince (rys. 1). Najpierw płynie w kierunku NE, by po kilku kilometrach zmienić kierunek o $90^{\circ}$ i na 9. kilometrze biegu przyjąć swój największy i właściwie jedyny dopływ wypływającą ze źródeł w Rosanowie i zasilaną wodą z wypływu w Ciosnach Ciosenkę. W rejonie wsi Swoboda, ok. 200 m powyżej ujścia do Dzierżąznej strugi o nazwie Czarnawka, znajduje się przekrój wodowskazowy zamykający zlewnię.

Dzierżązna i Ciosenka są rzekami, na których występują liczne obiekty zabudowy hydrotechnicznej. Są to zwykle stawy i towarzyszące im urządzenia piętrzące. $Z$ roku na rok ich liczba wzrasta. Mają one różne funkcje, choć dominuje hodowla ryb i rekreacja. Wszystkie te obiekty wpływają na podwyższenie ogólnej zasobności wodnej obszaru i wyrównywanie odpływu ze zlewni. Nabiera to szczególnego znaczenia, gdy weźmiemy pod uwagę jakość wody gromadzonej w stawach i zbiornikach. System rzeczny Dzierżąznej i Ciosenki odwadnia bowiem, dość wyjątkowy jak na warunki łódzkie, obszar podmiejski, z którego nadal odpływają oraz w którym retencjonowane są jeszcze wody stosunkowo czyste.

Badania sieci hydrograficznej na terenie zlewni Dzierżąznej przeprowadzono biorąc za podstawę mapę topograficzną w skali 1:25000. Przedstawiony na niej obraz sieci rzecznej aktualizowano i weryfikowano wielokrotnie w terenie oraz na podstawie zdjęć lotniczych. Należy zaznaczyć, że datowanie obrazu sieci hydrograficznej winno być powszechnie stosowane, gdyż jest ona zjawiskiem bardzo dynamicznym. Zmienia się zarówno w ciągu roku wraz $\mathrm{z}$ wahaniami zwierciadła wód podziemnych i rozkładem opadów, jak również z biegiem lat pod wpływem czynników długofalowych (fluktuacje elementów klimatu, zmiany związane ze stopniową zabudową obszaru, funkcjonowaniem budowli hydrotechnicznych, melioracją itp.).

Zagadnienie retencji powierzchniowej w zlewni, w tym problemy pojemności wodnej koryt są bardzo interesujące, a jednocześnie należą do najsłabiej poznanych $\mathrm{w}$ hydrologii. Wiąże się to oczywiście $\mathrm{z}$ dużą pracochłonnością 
i konieczną precyzją badań empirycznych oraz ich swoistą „ulotnością”, wynikającą z dużej dynamiki i sezonowości zjawiska. Może dlatego, wszelkie podejmowane próby szacowania wielkości całkowitej retencji powierzchniowej lub jej poszczególnych składowych, w tym próby wiązania jej $\mathrm{z}$ innymi charakterystykami fizycznogeograficznymi terenu, $\mathrm{np}$. $\mathrm{z}$ hierarchią sieci hydrograficznej, czy też badania jej zmienności sezonowej, są w mojej ocenie szczególnie wartościowe. W ogólności retencja powierzchniowa zlewni obejmuje: retencję koryt rzecznych, retencję wód stojących (jeziora, stawy i inne zbiorniki), retencję szaty roślinnej (intercepcję), retencję powierzchni gleby (detencję roli), retencję depresyjną (w zagłębieniach terenu, mokradłach, torfowiskach), retencję pokrywy śnieżnej (okresowa).

$\mathrm{Z}$ retencją powierzchniową nieodmiennie wiąże się zagadnienie małej retencji, czyli różnego typu działań powodujących poprawę jakości i ilości zasobów wodnych wskutek spowolnienia obiegu wody i innych substancji w zlewni (Mioduszewski 1997). W obrębie małej retencji wymienia się zwykle: retencję krajobrazową (uzależnioną od pojemności wodnej: mokradeł, użytków ekologicznych, oczek wodnych, pasów ochronnych i zadrzewień, lasów i łąk), glebową (zależną od: struktury gleby, zabiegów agromelioracyjnych, zawartości próchnicy itp.), wód gruntowych (determinowaną przez: wielkość infiltracji i strukturę odpływu, charakter melioracji itp.), sieci hydrograficznej (związaną z pojemnością: naturalnych i sztucznych zbiorników wodnych, rowów, cieków, a nawet całych dolin) oraz retencję śnieżną. Podejmując odpowiednie działania w obrębie wskazanych elementów środowiska, można nie tylko poważnie zwiększyć zasoby wodne obszaru, ale również zmniejszyć tempo ich krążenia. Małą retencję zalicza się jednocześnie do tzw. retencji niesterowalnej, czyli takiej, której zasobów nie da się dowolnie regulować. Działa ona niejako „automatycznie” zwiększając pojemność wodną obszaru. Mimo to wiedza o niej i dbałość o jej utrzymanie, a nawet rozbudowę, należą obecnie do podstawowych zadań lokalnej gospodarki wodnej, zwłaszcza że jest to przeważnie retencja „ekologicznie czysta”, a przez to niezwykle pożyteczna dla utrzymania bioróżnorodności.

Korzyści jakie niesie rozbudowa małej retencji, zwłaszcza zbiornikowej, są wielorakie. Od zaspakajania potrzeb gospodarczych różnych użytkowników (ujęcia wody, energetyka, nawadnianie, rybactwo, ochrona przeciwpożarowa), przez stymulację rozwoju: sportu, turystyki i rekreacji, po kształtowanie formy: obiektów urbanistycznych, krajobrazu i wreszcie całego środowiska przyrodniczego. Trudno też nie wspomnieć o ochronie przeciwpowodziowej i przeciwdziałaniu suszom hydrologicznym. Obok skutków i oddziaływań pozytywnych, mała retencja zbiornikowa generuje także szereg zjawisk niekorzystnych. Dość tu wymienić: podtapianie gruntów i związane $\mathrm{z}$ tym zmiany w sposobie ich użytkowania oraz przemiany ekologiczne, konieczność przebudowy infrastruktury technicznej terenu (dróg, sieci energetycznych i telekomunikacyjnych 
itp.), zalanie i wyłączenie z użytkowania znacznych połaci gruntów, obniżenie jakości wody w efekcie zrzutów ze stawów hodowlanych i rekreacyjnych, czy wreszcie przemiany warunków termiczno-wilgotnościowych obszaru.

Małe zbiorniki wodne lokalizowane są zwykle w dolinach rzecznych, a zatem na terenach o najwyższej produktywności biologicznej i bioróżnorodności. Trzeba też pamiętać, że zalanie tych terenów powoduje nie tylko ograniczenie produkcji biomasy, ale również wydatnie zmniejsza liczbę występujących tam gatunków. Warto zatem zadbać o to, by powierzchnia zatapiana była jak najmniejsza, a siedliska nadrzeczne odbudowywane (Żelazo 1997). Przegrodzenie rzeki zaporą lub jazem wywołuje też istotne zmiany w jej korycie. Zmniejsza się prędkość płynięcia rzeki, a w konsekwencji zaburzony zostaje jej naturalny reżim przepływu wody i transportu rumowiska. Zmieniają się też właściwości fizyczne i chemiczne wody. Przynosi to w efekcie wzrost sedymentacji (np. zamulanie biologicznie czynnych powierzchni koryta cieku oraz wypłycanie misy zbiornika), spadek zmącenia wody (maleje transport substancji i organizmów), wzrost zużycia tlenu oraz szereg innych, nie zawsze korzystnych, skutków (Zalewski, Wiśniewski 1997).

W celu obliczenia retencji koryt rzecznych i zbiorników istniejących w zlewni Dzierżąznej, wiosną i jesienią 1999 r., wykonano na tym terenie stosowne pomiary. Ustalono powierzchnie ponad 120 przekrojów zwilżonych koryt systemu oraz przesondowano i zmierzono powierzchnie lustra wody we wszystkich, nawet najmniejszych zbiornikach wód stojących - poczynając od stawów ogrodowych, a kończąc na dużych zbiornikach wodnych (Jokiel 2002). W kilku przypadkach wykorzystano istniejące dokumentacje projektowe. Pomiary te posłużyły do oszacowania - w dwu terminach (wiosna i jesień) - objętości wody i powierzchni jej lustra $\mathrm{w}$ korytach cieków oraz $\mathrm{w}$ istniejących wówczas zbiornikach wodnych zlewni.

W przeliczeniu na wskaźnik odpływu, przeciętne zasoby wód gromadzonych w sieci hydrograficznej tej zlewni wynoszą ok. 4,5-4,7 mm, z czego na koryta przypada zaledwie $0,1 \mathrm{~mm}$. Biorąc pod uwagę średni odpływ roczny ze zlewni Dzierżąznej równy ok. $162 \mathrm{~mm}$, zapas ten pozwoliłby na podtrzymanie przepływu rzeki, na poziomie średnim, najwyżej przez ok. 10 dni. W obu sezonach, retencja korytowa stanowi tylko 2-2,5\% ogólnej masy wody gromadzonej w sieci hydrograficznej. Pozostałą część tworzą wody stojące, retencjonowane w sztucznych, rzadziej w naturalnych, zbiornikach wodnych. Analizując wielkość retencji korytowej, warto zauważyć, że największy odsetek zasobów mieszczą dwa główne cieki - Ciosenka i Dzierżązna. Ich dopływy są zaś małe, występują okresowo i zawierają od $15 \%$ (w marcu), do niecałych $5 \%$ tejże retencji we wrześniu. Wart odnotowania jest też fakt, że większość zbiorników i stawów włączona jest do sieci hydrograficznej. Jednocześnie spotkać tu można zarówno obiekty o zasobach sterowalnych, jak i niesterowalnych. Retencja zbiornikowa $\mathrm{w}$ zlewni związana jest $\mathrm{z}$ korytami cieków i zasilana niemal wyłącznie wodami powierzchniowymi. Stosunkowo rzadko pojawiają się wypeł- 
nione wodą wyrobiska $\left(3,8 \times 10^{4} \mathrm{~m}^{3}\right.$ wody - glinianka w rejonie Dąbrówki Strumiany) oraz okresowe, zasilane opadem lub wodami podziemnymi, sadzawki i stawy śródpolne.

Powiązania retencji wód stojących $\mathrm{z}$ retencją korytową znajdują swoje odzwierciedlenie w obrazie przestrzennego zróżnicowania chwilowych, całkowitych zasobów wód powierzchniowych w zlewni (rys. 8). Ponad 90\% powierzchni zlewni pozbawiona jest jakichkolwiek form tej retencji, a większość jej zasobów koncentruje się w obrębie dwu dolin rzecznych oraz na terenach, które do nich bezpośrednio przylegają. Jeśli uwzględnimy zasoby wodne badanego obszaru wyrażone średnim odpływem rzecznym $(162 \mathrm{~mm})$, widzimy jasno, że istnieją dziś spore, niewykorzystane jeszcze rezerwy czystych jak dotąd wód rzecznych. Wody te mogą zostać z pożytkiem dla mieszkańców oraz środowiska i krajobrazu przeznaczone na potrzeby małej retencji. Dotyczy to w szczególności retencji na potrzeby rekreacji, a w sensie przestrzennym, górnej i środkowej Ciosenki (okolice wsi: Rosanów i Ciosny) oraz dolnej Dzierżąznej (rejon wsi Głowa).

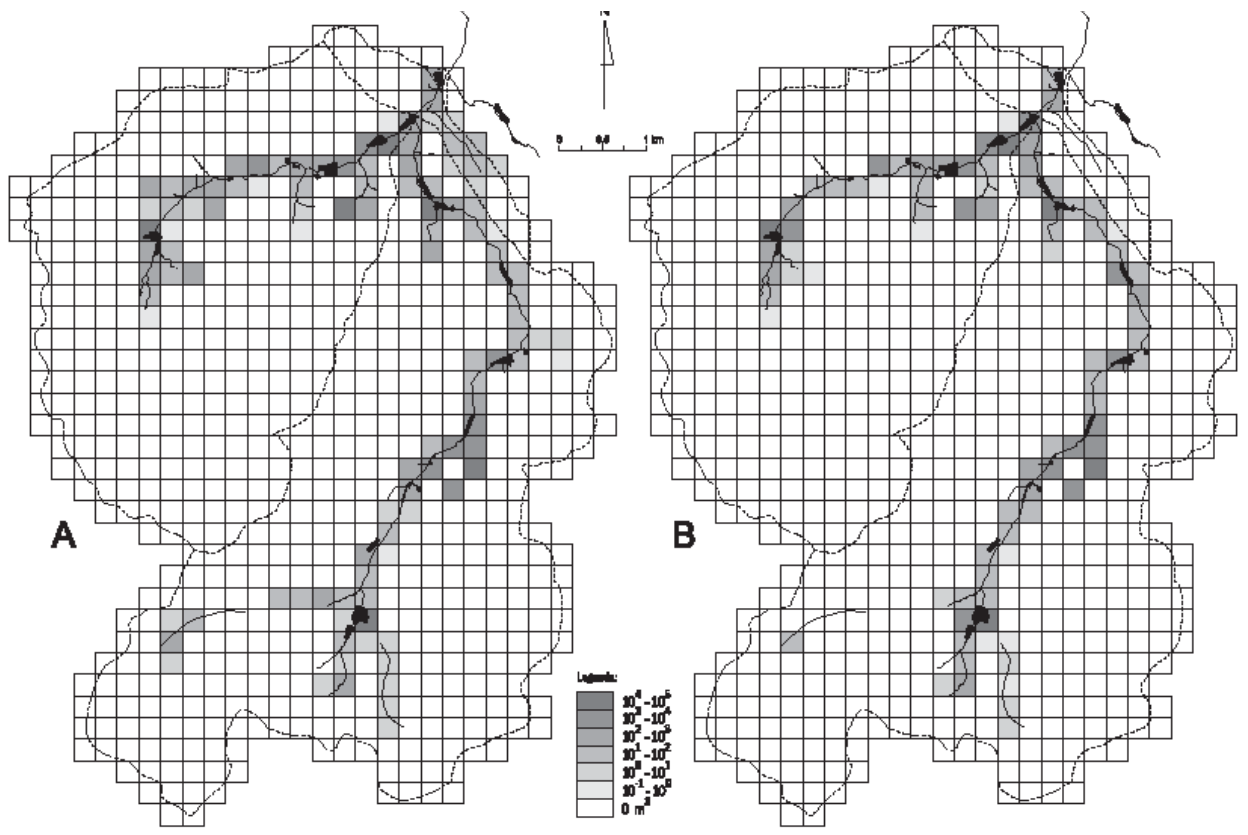

Rys. 8. Retencja sieci hydrograficznej w zlewni Dzierżąznej w 1999 r. [m³] A - wiosna 1999; B - jesień 1999

Fig. 8. Rivers and ponds retention in the Dzierżązna drainage basin $\left[\mathrm{m}^{3}\right]$ A - spring of the year 1999; B - autumn of the year 1999 
Z drugiej jednak strony, należy zacząć skrupulatnie przestrzegać wytycznych, zawartych w wydanych dotąd pozwoleniach wodno-prawnych na użytkowanie wód obu strug, jak też zalegalizować (wydać stosowne pozwolenia) lub zlikwidować liczne, powstałe „na dziko”, piętrzenia i stawy. Niektóre z wydanych dotąd pozwoleń wymagają też weryfikacji. Gospodarowanie wodą rzeczną przez poszczególnych użytkowników jest dziś bowiem podporządkowane wyłącznie aktualnym potrzebom danego obiektu i użytkownika. Na przykład; spusty i pobory wody do stawów hodowlanych i rekreacyjnych odbywają się bez uwzględniania reżimu odpływu rzeki. Powoduje to często okresowe zalewanie znacznych fragmentów dolin, a w okresach poboru wody częściowy, a nawet całkowity zanik przepływu i przesuszenie den dolinnych. O konsekwencjach ekologicznych tych zjawisk nie ma nawet potrzeby tu wspominać. Uwaga ta dotyczy w szczególności górnego i środkowego odcinka Dzierżąznej.

\section{Retencja warstwy aeracji}

Przypowierzchniowa warstwa gruntu nie dość, że ukierunkowuje i tworzy relacje między różnymi formami odpływu pojawiającego się w zlewni, to stanowi jeszcze ważny zbiornik retencyjny zdolny do zatrzymania znacznych nawet ilości wody i innych substancji migrujących. Jeśli porowatość gruntu wynosi ok. 20\%, w jego 1-metrowej warstwie można teoretycznie zretencjonować opad o wysokości $200 \mathrm{~mm}$ (Paluch 1999). Warunkiem jest oczywiście na tyle długi kontakt wody z glebą, by umożliwił on nasycenie całej, metrowej warstwy gruntu. Zauważmy jednocześnie, że opad o takiej wysokości niemal dwukrotnie przekracza charakterystyczną dla nizin wysokość opadu dobowego o prawdopodobieństwie $1 \%$.

Maksymalną retencję przypowierzchniowej warstwy aeracji (ryzosfery) zlewni Dzierżąznej obliczono, wykorzystując propozycję Thornthwaite'a-Mathera, uwzględniającą, przy jej ocenie, sposób użytkowania i rodzaj utworów powierzchniowych (Thornthwaite i in. 1961). Podaną przez autorów typologię, rozbudowano nieco wykorzystując inne dane i analizy (Olechnowicz-Bobrowska 1978; Sarnacka i in. 1983; Kędziora 1995). Zróżnicowanie przestrzenne wyróżnionych klas retencji maksymalnej warstwy przypowierzchniowej prezentuje rys. 9. Mapę tę skonstruowano w konwencji rastrowej. W pierwszym etapie, na podstawie „konwencjonalnych” map: sposobu użytkowania gruntów i przepuszczalności utworów powierzchniowych, uzyskano obraz przestrzennego rozmieszczenia 25 typów użytkowania terenu, wydzielonych na podstawie charakteru osadów powierzchniowych. Obraz ten przetransformowano, łącząc z sobą typy o takiej samej pojemności wodnej. W kolejnym kroku analizy rysunek ten przekształcono w mapę rastrową. W tym celu obliczono dla każdego oczka siatki średnią ważoną pojemność maksymalną. Poletka pogrupowano, przyjmując szerokość przedziału równą $50 \mathrm{~mm}$. Uzyskano tym samym 6 przedziałów zmienności $R_{\max }$. Górny przedział pozostawiono otwarty. 
Obraz przestrzennego zróżnicowania maksymalnej retencji przypowierzchniowej warstwy aeracji, przedstawiony na tej mapie, jest interesujący. Ponownie i to bardzo wyraźnie zaznacza się różnica między zlewniami cząstkowymi Ciosenki i Dzierżąznej. W pierwszej - strefy wododziałowe charakteryzują się relatywnie podwyższoną pojemnością, zaś środkowa część zlewni ma tę pojemność stosunkowo małą. W przypadku Dzierżąznej jest odwrotnie. Środkową część jej obszaru charakteryzują wartości wyższe od średniej, zaś w obrębie działów wodnych, pojemność wodna warstwy przypowierzchniowej jest wyraźnie od niej niższa. Średnia pojemność strefy przypowierzchniowej zlewni Dzierżąznej jest także o kilkanaście procent większa niż przeciętna pojemność zlewni Ciosenki.

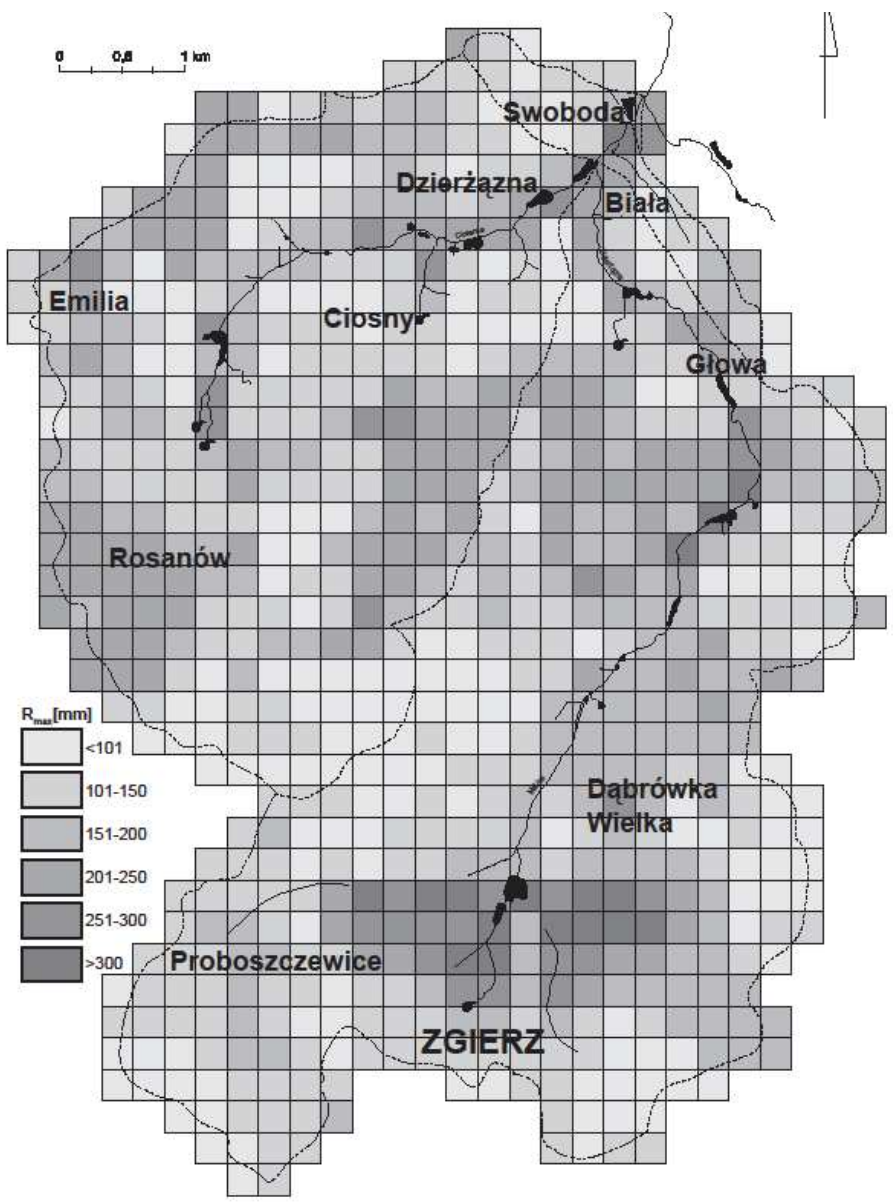

Rys. 9. Maksymalna retencja warstwy przypowierzchniowej w zlewni Dzierżąznej

Fig. 9. Maximum retention of the shallow surface layer in the Dzierżązna drainage basin 
Przeciętną wartość $R_{\max }$ dla zlewni otrzymano jako średnią ważoną. W obliczeniach uwzględniono przy tym powierzchnie zajmowane przez wody powierzchniowe (stawy, koryta). Dla uproszczenia przyjęto dla nich $R_{\max }$ równą $400 \mathrm{~mm}$. Obliczona średnia dla zlewni maksymalna pojemność strefy korzeniowej jest równa $157 \mathrm{~mm}$. Minimalna pojemność wodna tej strefy $\left(R_{\min }\right)$, przyjmowana zwykle na poziomie $0,4 R_{\max }$ (Jaworski 1986), wyniosła $63 \mathrm{~mm}$. Zauważmy zatem, że zasoby użyteczne (dynamiczne) wynoszą $94 \mathrm{~mm}$.

W latach 1998-2001, retencja strefy przypowierzchniowej zmieniała się w granicach wyznaczonych przez nakreślone wyżej ekstrema $\left(R_{\max }\right.$ i $\left.R_{\min }\right)$. Od stycznia do kwietnia (czasem do marca) stany retencji utrzymywały się na poziomie maksymalnym, a nadwyżki opadu uzupełniały zasoby wód podziemnych. Od czerwca do września (oprócz roku 2001), retencja malała zwykle do minimum $\left(R_{\min }\right)$, co skutkowało brakiem nadwyżek wodnych (Jokiel 2002).

\section{Retencja warstwy saturacji}

Rozpatrując zagadnienie dynamicznych, odnawialnych zasobów wód podziemnych, przywołujemy często pojęcie strefy aktywnej wymiany. Rozumiemy przez nią przypowierzchniową, ograniczoną przestrzeń litosfery, w której gromadzone zasoby wód podziemnych, znajdują się pod wpływem drenującego oddziaływania sieci hydrograficznej, w tym: źródeł, jezior, rzek oraz obszarów podmokłych i bezodpływowych, a występujące w niej różnice ciśnień piezometrycznych stwarzają warunki do ich sczerpania (Jokiel 1994). Zauważmy, że w odniesieniu do pojedynczego obiektu hydrograficznego, np. rzeki, pojęcie strefy aktywnej wymiany jest bliskie definicji zlewni podziemnej. Można jednak dostrzec również i różnice np. między całkowitymi zasobami wód podziemnych w tak zdefiniowanej strefie, a jej zasobami odnawialnymi. Bowiem ,poza” strefą mogą się znaleźć wody, które wskutek specyficznych warunków hydrogeologicznych są „uwięzione”, a ich drenaż naturalny jest bardzo utrudniony. Jako przykład można tu wskazać, jakże częste na obszarach pokrytych płaszczem osadów polodowcowych, tzw. wody zawieszone (np. śródglinowe).

Warto także podkreślić „kaskadowy” charakter strefy aktywnej wymiany. Wody podziemne, które dla niewielkiego cieku są apotamiczne i nie są przez niego drenowane (chociażby wskutek głębokiego położenia zwierciadła), mogą jednak zasilać jego recypienta lub inną rzekę, których głębokość wcięcia erozyjnego zapewnia istnienie gradientu hydraulicznego. Z rozważań tych jasno wynika, że ocena przestrzennego zasięgu strefy aktywnej wymiany, jak też określenie jej zasobów odnawialnych nie są proste i wymagają szczegółowego rozpoznania warunków hydrogeologicznych obszaru oraz skali i charakteru powiązań wód podziemnych z siecią hydrograficzną.

Przeciętne miąższości stref aktywnej wymiany zlewni Ciosenki i Dzierżąznej do ujść oraz całej zlewni Dzierżąznej, do wodowskazu w Swobodzie wynoszą odpowiednio: $14,7 \mathrm{~m}, 20,3 \mathrm{~m}$ i $18,1 \mathrm{~m}$. Stosując metodę zaproponowaną we wcześniejszej pracy autora (Jokiel 1999) obliczono także objętości stref 
aktywnej wymiany wymienionych zlewni. Są one równe: $0,262 \mathrm{~km}^{3}$ - Ciosenka; $0,483 \mathrm{~km}^{3}$ - Dzierżązna i $0,777 \mathrm{~km}^{3}$ - cała zlewnia (zamknięta wodowskazem w Swobodzie).

Przeprowadzone w początkowym okresie badań kartowanie hydrogeologiczne ujawniło ukształtowanie zwierciadła wody pierwszego, najpłytszego poziomu wodonośnego. Stwierdzono, że głębokość do tego poziomu jest w zlewni Dzierżąznej bardzo zróżnicowana i zawiera się w przedziale: od kilkudziesięciu cm do ponad $20 \mathrm{~m}$ (Jokiel 2002). Warto podkreślić, że w sposób względnie ciągły rośnie ona wraz ze wzrostem odległości od cieków. Mapę miąższości warstwy aeracji, podobnie jak inne prezentowane mapy, wykonano w postaci rastrowej, przy czym miąższość w oczku siatki obliczono jako średnią ważoną (rys. 10). Dla zobrazowania zastosowano standardowe, najczęściej używane przedziały głębokości (miąższości): 0-1, 1-2, 2-5..., 20-30 m ppt. Warto tu zwrócić uwagę na dość dużą różnicę średniej miąższości i objętości strefy czynnej w obu zlewniach cząstkowych. Powiązanie tego faktu z przeciętną miąższością stref aeracji obu zlewni, winno dać pogląd na stopień zawodnienia warstwy saturacji oraz pomóc przy ocenie sposobu i intensywności zasilania cieków wodami podziemnymi.

Średnie ważone głębokości zwierciadła wody podziemnej w poszczególnych zlewniach cząstkowych oraz w całej zlewni Dzierżąznej wynoszą odpowiednio: Ciosenka - 7,1 m, Dzierżązna - 10,8 m, cała zlewnia - 9,0 m. Prawie 55\% zlewni cząstkowej Dzierżąznej to obszary, na których zwierciadło wody znajduje się na głębokościach większych niż $10 \mathrm{~m}$, natomiast tereny z bardzo płytko występującą wodą podziemną zajmują tylko nieco ponad $4 \%$ jej powierzchni. Zgoła inaczej przedstawia się sytuacja w zlewni Ciosenki. Blisko $60 \%$ jej powierzchni ograniczają hydroizobaty 2 i $10 \mathrm{~m}$, natomiast tylko na $20 \%$ jej obszaru, zwierciadło wody podziemnej występuje głębiej niż $10 \mathrm{~m}$. Równocześnie jednak dużo większe powierzchnie $(8,1 \%)$ zajmują tu tereny okresowo podmokłe (głębokość pierwszego poziomu $0-1 \mathrm{~m}$ ). Jeśli weźmiemy pod uwagę całą zlewnię Dzierżąznej, udział powierzchni o określonej miąższości strefy aeracji jest bardziej wyrównany niż w zlewniach cząstkowych. Obszary zakreślone przez poszczególne hydroizobaty stanowią od $6 \%$ do ponad $28 \%$ jej terytorium.

Porównanie, obliczonych wyżej, średnich miąższości strefy aktywnej wymiany i odpowiadających im średnich głębokości do zwierciadła wody pierwszego poziomu wskazuje, że we wszystkich trzech zlewniach warstwa aeracji stanowi blisko połowę łącznej grubości strefy czynnej. Stąd zaś płynie wniosek, że w warunkach przeciętnego zasilania połowa drenowanego przez rzeki profilu czwartorzędu może być potencjalnie zawodniona.

Aby rozpoznać stopień zagrożenia i odporność wód podziemnych na zanieczyszczenie oraz przedsięwziąć odpowiednie kroki w celu ochrony ich jakości, 


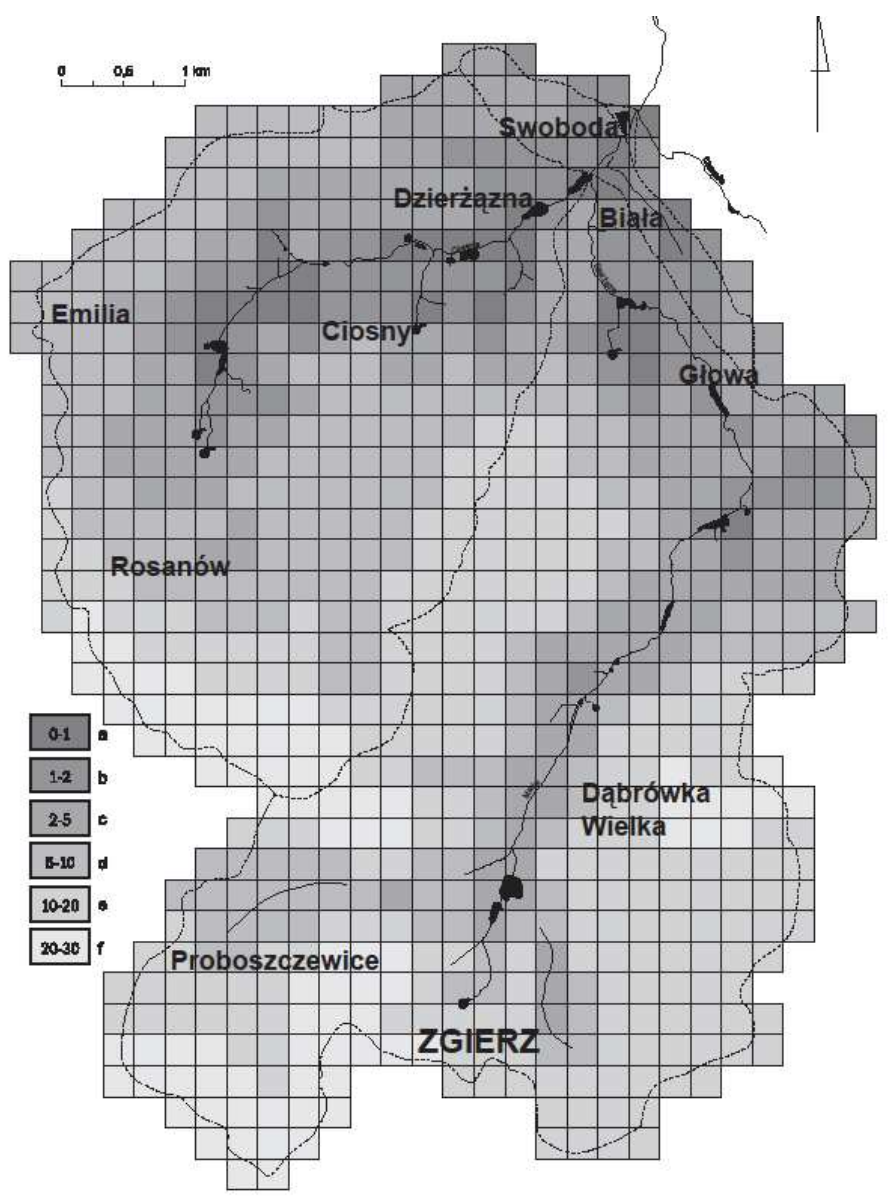

Rys. 10. Głębokość do zwierciadła wód podziemnych w zlewni Dzierżąznej [m p.p.t.]

Fig. 10. Depth of the first groundwater horizon in the Dzierżązna drainage basin [metres below ground level]

niezbędna jest identyfikacja ogniska zanieczyszczeń, jak też rozpoznanie parametrów wnętrza przestrzeni migracji zanieczyszczeń, w tym poziomu wodonośnego i jego otoczenia, np. strefy wnikania i przenikania nieczystości. W ostatnim czasie coraz większą uwagę przywiązuje się do rozpoznania bezpośredniego otoczenia zbiorowiska wody podziemnej. Uwzględniając fakt, że większość zanieczyszczeń pochodzi z powierzchni, ważna jest także ocena możliwości absorpcji zanieczyszczeń przez utwory nadległe, czy sąsiadujące. Traktuje się je przy tym jako rodzaj kapelusza ochronnego, który jest w stanie nie tylko zatrzymać, ale również dezaktywować niektóre substancje. Zagadnienia te są szczególnie istotne przy ocenie zagrożenia wód podziemnych w dużej skali, a więc w badaniach podatności określonych zbiorowisk wód 
podziemnych na zanieczyszczenia obszarowe. Pamiętać należy, że kierunki przepływu wody, w tym wód podziemnych, wyznaczają najistotniejsze drogi migracji substancji $\mathrm{w}$ środowisku. Zatem rozpoznanie dróg obiegu wody umożliwia wskazanie sposobów przeciwdziałania rozprzestrzenianiu się zanieczyszczeń i ich neutralizacji.

Przegląd różnego rodzaju metod i procedur służących wykonywaniu tego typu analiz znajdziemy w pracy pod redakcją A. Kleczkowskiego (1984) oraz w monografii W. Chełmickiego (1997). W tej ostatniej znajdziemy szereg interesujących metod pozwalających w wiarygodny i, co ważne stosunkowo prosty sposób dokonać waloryzacji stopnia zagrożenia danego zbiorowiska wód podziemnych na zanieczyszczenia pochodzące z powierzchni. Jedną z prezentowanych w tej pracy metod jest procedura $G O D$, zaproponowana przez Fostera w $1987 \mathrm{r}$.

Na podstawie znajomości i parametryzacji: stopnia izolacji poziomu wodonośnego, charakteru wodonośca (rodzaj poziomu wodonośnego) i głębokości jego występowania, uzyskujemy charakterystykę liczbową, pozwalającą zwaloryzować podatność danego poziomu na zanieczyszczenie substancjami dostarczanymi $\mathrm{z}$ powierzchni. Procedurę tę, po niewielkich zmianach, zastosowano do oceny podatności na zanieczyszczenia pierwszego poziomu wodonośnego w zlewni Dzierżąznej. Szczegóły metodyczne zaproponowanego rozwiązania szczegółowego znaleźć można w opracowaniu autora (2002). Obraz przestrzenny przeprowadzonej waloryzacji przedstawia rys. 11 . Wynika z niego jasno, że najbardziej narażone na degradację są wody podziemne górnej części zlewni Ciosenki - okolice Rosanowa (zlewnia podziemna zespołu bardzo wydajnych źródeł w Rosanowie) oraz płytki poziom wodonośny rejonu Jeżewa. Warto zwrócić szczególną uwagę na okolice Rosanowa. Obszar ten jest bowiem obecnie intensywnie zagospodarowywany rekreacyjnie - działki leśne, domy letniskowe itd. Wiąże się z tym powstawanie wielu dzikich ognisk zanieczyszczeń powierzchniowych (śmietniska, doły kloaczne itp.) i podziemnych (szamba, doły chłonne). Mamy tu do czynienia z kumulacją zagrożeń, gdyż dużej, potencjalnej podatności towarzyszą liczne i stale powstające ogniska zanieczyszczeń. Osobnym problemem jest systematyczna degradacja tryskającego tu, najwydajniejszego w tej części Polski, zespołu dwu źródeł o łącznej, średniej wydajności ok. $50 \mathrm{dm}^{3} \cdot \mathrm{s}^{-1}$ (Moniewski, Stolarska 2007). Podkreślmy, że dotyczy to nie tylko niszy źródłowej, zasypywanej odpadkami, ale, jak wykazałem wyżej, istnieje całkiem realna możliwość zanieczyszczenia całej zlewni podziemnej źródeł, w tym wypływającej z nich wody.

Najmniej podatne na zanieczyszczenia (wyjąwszy dolinę Dzierżąznej) są tereny położone $\mathrm{w}$ górnej części badanej zlewni. Jest to szczęśliwy zbieg okoliczności, bowiem właśnie te obszary poddane są dziś dużej presji związanej z rozwojem drobnego przemysłu, urbanizacją i procesami, które im towarzyszą. 


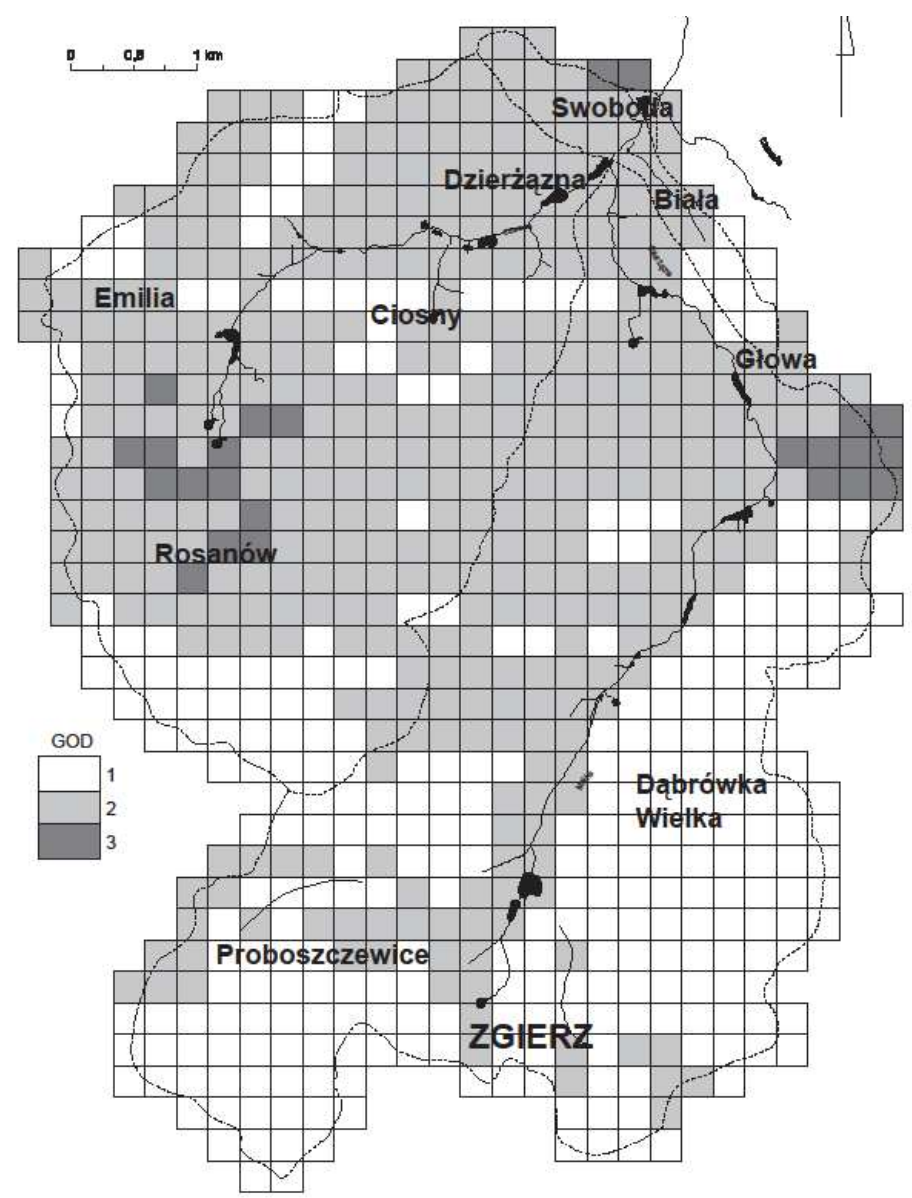

Rys. 11. Podatność płytkich wód podziemnych zlewni Dzierżąznej na imisję zanieczyszczeń z powierzchni terenu

1 - mała podatność; 2 - średnia podatność; 3 -duża podatność

Fig. 11. Vulnerability of shallow groundwater to pollution in the Dzierżązna drainage basin (Foster formula)

1 - low vulnerability; 2 - medium vulnerability; 3 - high vulnerability

$\mathrm{Na}$ dodatek są to tereny o gęstej sieci różnego rodzaju wyrobisk poeksploatacyjnych, a więc miejsc szczególnie sprzyjających infiltracji zanieczyszczeń. Mała podatność na zanieczyszczenia nie zwalnia od dbałości o te tereny, zwłaszcza że zlokalizowano na nich kilka ważnych z punktu widzenia miasta i gminy Zgierz, ,czułych” na degradację inwestycji hydrotechnicznych. Dość tu wymienić komunalne ujęcia wód podziemnych oraz zalew w Malince. W pozostałej części zlewni stopień zagrożenia płytkich wód podziemnych zanieczyszczeniami pochodzącymi z powierzchni jest umiarkowany, co nakazuje ostrożność w gospodarowaniu tymi gruntami. Dotyczy to w szczególności 
terenów sandru grotnicko-lućmierskiego oraz rejonu Białej. Kontakty hydrauliczne między różnymi poziomami wodonośnymi są tam powszechne i istnieje możliwość wielkoprzestrzennej migracji zanieczyszczeń (w pionie oraz w poziomie). Jednocześnie są to tereny dość intensywnie zagospodarowywane rekreacyjnie, gdzie w sposób niekontrolowany wzrasta gwałtownie ilość produkowanych odpadów i ścieków. Przykładem są tu okolice wsi Ciosny i Głowa.

Zadaniem współczesnej hydrologii jest nie tylko identyfikacja i modelowanie naturalnych, czy też paranaturalnych stosunków wodnych, ale także, a na niektórych już obszarach nawet przede wszystkim, ich stały monitoring, połączony z rejestrowaniem zmian zachodzących współcześnie. Badania takie powinny też umożliwiać stawianie prognoz i opracowywanie alternatywnych scenariuszy zmian tych stosunków, które mogą zaistnieć w wyniku przemian zachodzących współcześnie $\mathrm{w}$ wektorze czynników naturalnych i antropogenicznych. Pod tym względem monitorowany fragment strefy podmiejskiej Łodzi jest bardzo interesującym obiektem badawczym. Jest to bowiem typowy przykład obszaru znajdującego się w okresie przejściowym od stanu agrarnego do fazy wczesnej urbanizacji. Zatem i stosunki wodne wchodzą w okres, w którym ustalają się dopiero nowe proporcje w małym obiegu wody. Jego nowy kształt zależeć będzie zatem w równym stopniu od warunków naturalnych, jak i od charakteru i tempa działań podejmowanych tu przez człowieka. Być może w ogóle kluczem do prawidłowej gospodarki zasobami wodnymi na obszarach podmiejskich jest uświadomienie sobie przez człowieka własnej roli $\mathrm{w}$ ich kształtowaniu i redystrybucji w środowisku.

\section{LITERATURA}

Bartnik A, Moniewski P., 2012, The impact of A2 motorway on basic physical and chemical water characteristics of a small sub-urban catchment in central Poland, [w:] HydroPredict'2012, Volume of abstract, Nachtnebel P., Kovar K. (eds), $3^{\text {rd }}$ International Interdisciplinary Conference on Predictions for Hydrology, Ecology and Water Resources Management: Water Resources and Changing Global Environment, Vienna, Austria, s. 42-43.

Byczkowski A., 1996, Hydrologia [Tom I i II], Wydawnictwo SGGW, Warszawa, 375 s.; 333 s.

Chełmicki W., 1997, Degradacja i ochrona wód - „Jakość”, Wydawnictwo UJ, Kraków, 252 s.

Czarnecka H., 1986, Parametry fizycznogeograficzne stosowane w obliczeniach maksymalnych przeptywów prawdopodobnych, Prace Inst. Bad. Bud. Dróg i Mostów, nr 3-4, Warszawa, s. 151-166. 
Jaworski J., 1986, Opór dyfuzyjny pokrywy roślinnej na tle składników bilansu wodnego i cieplnego, Wiadomości IMGW, z. 4, Warszawa, s. 24-39.

Jokiel P., 1994, Zasoby, odnawialność i odptyw wód podziemnych strefy aktywnej wymiany w Polsce, ,Acta Geographica Lodziensia”, 66-67, Wydawnictwo ŁTN, Łódź, $236 \mathrm{~s}$.

Jokiel P., 1999, Objętość $i$ stan zawodnienia stref aktywnej wymiany matych zlewni rzecznych, „Czasopismo Geograficzne”, z. 3-4, Wrocław, s. 337-348.

Jokiel P., 2002, Woda na zapleczu wielkiego miasta, Wydawnictwo IMGW, Warszawa, $148 \mathrm{~s}$.

Kędziora A., 1995, Podstawy agrometeorologii, PWRiL, Poznań, 264 s.

Klatkowa H., 1972, Paleogeografia Wyżyny Łódzkiej $i$ obszarów sąsiednich podczas zlodowacenia warciańskiego, „Acta Geographica Lodziensia”, 28, Ossolineum, Łódź, $220 \mathrm{~s}$.

Klatkowa H. (red.), 1993, Szczegótowa mapa geologiczna (ark. Zgierz), PIG, Warszawa.

Kleczkowski A., 1984, Ochrona wód podziemnych, Wydawnictwo Geologiczne, Warszawa, $328 \mathrm{~s}$.

Olechnowicz-Bobrowska B., 1978, Parowanie potencjalne $w$ okresie wegetacyjnym w Polsce, Zeszyty Naukowe Akademii Rolniczej w Krakowie, rozpr. habil. nr 67, Kraków, 173 s.

Mioduszewski W.,1997, Mała retencja $i$ polityka melioracyjna, Zeszyty Naukowe Komitetu PAN „Człowiek i Środowisko”, z. 17, Instytut Ekologii PAN, Dziekanów Leśny. s. 49-63.

Moniewski P., Stolarska M., 2007, Podstawowe właściwości fizykochemiczne wód wniszy źródliskowej Rosanów I, [w:] Jokiel P., Moniewski P., Ziułkiewicz M. (red.), Źródta Polski. Wybrane problemy krenologiczne, Wydawnictwo Regina Poloniae, Częstochowa, s. 213-224.

Moniewski P., Stolarska M., Tomalski P., 2007, Zmiany warunków krążenia wody w zlewni Dzierżaznej pod wptywem budowy autostrady A2 w okolicach Łodzi, [w:] Michalczyk Z. (red.), Obieg wody w środowisku naturalnym i przeksztatconym, Wydawnictwo UMCS, Lublin. s. 394-401.

Moniewski P., Stolarska M., 2008, Wptyw przeksztatceń infrastruktury drogowej na podstawowe cechy fizykochemiczne wód powierzchniowych matej zlewni podmiejskiej, [w:] Bródka S. (red.), Problemy środowiska przyrodniczego miast; Problemy ekologii krajobrazu, t. 22, Bogucki Wydawnictwo Naukowe, Poznań-Warszawa, s. 285296.

Moniewski P., Tomalski P., 2008, Wptyw systemu odwodnienia autostrady na stosunki wodne małej zlewni, [w:] Baścik M., Partyka J. (red.), Wody na obszarach chronionych, Wydawnictwo Ojcowski PN i PTG, Ojców, s. 101-102.

Paluch J., 1999, Wykorzystanie małej retencji zlewni czastkowych do ochrony wód powierzchniowych i podziemnych, „Gospodarka Wodna”, nr 5, 6, Warszawa, s. 172176, s. 213-216.

Ryszkowski L., 1994, Przeciwerozyjne działania na obszarach wiejskich, Roczniki Akademii Rolniczej w Poznaniu, nr 266, Melior. i Inż. Środ., nr 14, Poznań. s. 7587.

Sarnacka S., Brzeska J., Świerczyńska H., 1983, Wybrane metody wyznaczania ewapotranspiracji potencjalnej, Mat. Bad. IMGW, seria: Gosp. Wod. i Ochr. Wód., Wydawnictwo IMGW, Warszawa, ss. 1-35. 
Siudek R.W., 2012, Opady atmosferyczne na posterunku KHiGW w Ciosnach w przekroju wieloletnim, Praca magisterska (maszynopis w KHiGW WNG UŁ), Łódź, ss. 138.

Soczyńska U., 1989, System hydrologiczny zlewni i modelowanie procesów obiegu wody, [w:] Soczyńska U. (red.), Procesy hydrologiczne, PWN, Warszawa. s. 9-19.

Thornthwaite C.W., Mather J.R., Carter D.B., 1961, Water balance maps of Eastern North America, Przegląd Zagranicznej Literatury Geograficznej, z. 1, Warszawa, $124 \mathrm{~s}$.

Zalewski M., Wiśniewski R. (red.), 1997, Zastosowanie biotechnologii ekosystemalnych do poprawy jakości wód, PAN, Zeszyty Naukowe, 18, Kom. Człowiek i Środowisko, Warszawa, s. 5-22.

Żelazo J., 1997, Małe obiekty retencyjne a rolnictwo i środowisko przyrodnicze, Materiały Konferencyjne SITWM „Mała retencja wodna”, Sielpia Wielka. s. 21-25.

\section{Źródła internetowe}

http://hydro.geo.uni.lodz.pl.

\section{SUMMARY}

In the article some problems connected with the role of physiographical conditions in water circulation process and migration of substances within a little drainage basin situated on the outskirts of a large town (Łódź) were discussed. The description was given in two basic aspects: runoff forming and retention shaping. The results referred especially to the role of relief of the Earth's surface (inclination of slopes), soil permeability and ground susceptibility to shaping the runoff forms. As regards water retention, surface retention of channels and waterbodies, water capacity of the rhizoshpere, and groundwater resources were mentioned. Great attention was given to the presentation and analyses of spatial variability of the drainage basin characteristics. To illustrate it digital maps were used, which were based on elementary squares network (fig. 3-11). These maps are the most important results of the research.

Keywords: water circulation, small basins, central Poland 